\title{
Prevention approaches in a preclinical canine model of Alzheimer's disease: benefits and challenges
}

\author{
Paulina R. Davis ${ }^{1,2}$ and Elizabeth Head ${ }^{1,2}$ * \\ ' Sanders-Brown Center on Aging, University of Kentucky, Lexington, KY, USA \\ ${ }^{2}$ Department of Molecular and Biomedical Pharmacology, University of Kentucky, Lexington, KY, USA
}

Edited by:

Cesare Mancuso, Catholic University of the Sacred Heart, Italy

\section{Reviewed by:}

Maria José Diógenes, University of Lisbon, Portugal

Troy Townsend Rohn, Boise State

University, USA

\section{${ }^{*}$ Correspondence:}

Elizabeth Head, Sanders-Brown

Center on Aging and Department of Molecular and Biomedical

Pharmacology, University of Kentucky, 203 Sanders-Brown Building, 800

South Limestone Street, Lexington, KY 40536, USA

e-mail: elizabeth.head@uky.edu
Aged dogs spontaneously develop many features of human aging and Alzheimer's disease (AD) including cognitive decline and neuropathology. In this review, we discuss agedependent learning tasks, memory tasks, and functional measures that can be used in aged dogs for sensitive treatment outcome measures. Neuropathology that is linked to cognitive decline is described along with examples of treatment studies that show reduced neuropathology in aging dogs (dietary manipulations, behavioral enrichment, immunotherapy, and statins). Studies in canine show that multi-targeted approaches may be more beneficial than single pathway manipulations (e.g., antioxidants combined with behavioral enrichment). Aging canine studies show good predictive validity for human clinical trials outcomes (e.g., immunotherapy) and several interventions tested in dogs strongly support a prevention approach (e.g., immunotherapy and statins). Further, dogs are ideally suited for prevention studies as they the age because onset of cognitive decline and neuropathology strongly support longitudinal interventions that can be completed within a 3-5 year period. Disadvantages to using the canine model are that they lengthy, use laborintensive comprehensive cognitive testing, and involve costly housing (almost as high as that of non-human primates). However, overall, using the dog as a preclinical model for testing preventive approaches for $A D$ may complement work in rodents and non-human primates.

Keywords: antioxidant diet, atorvastatin, behavioral enrichment, beta-amyloid, combination treatment, dog, immunotherapy, statin

\section{INTRODUCTION}

Alzheimer's disease (AD) is a progressive dementia associated with the accumulation of beta-amyloid $(\mathrm{A} \beta)$ plaques and neurofibrillary tangles (NFT; McKhann et al., 1984; Mirra, 1997). Currently five drugs are approved for use by the FDA to manage the symptoms of $\mathrm{AD}$, although none target disease pathways and all may provide only symptomatic relief. These drugs include donepezil, rivastigmine, tacrine, galantamine, and memantine (Aisen et al., 2012). However, these five approved drugs target only two pathways, one involving acetylcholinesterase inhibition and the second is an NMDA receptor antagonist. Thus, preclinical studies are critical for developing and testing new disease-modifying interventions that can be taken to clinical trials in patients with $A D$. Typically, studies in rodents are the earliest steps in this process to screen drugs that target $\mathrm{AD}$ pathways with most preclinical studies of AD interventions using transgenic mouse models of AD. Subsequently, safety studies in humans are followed by a clinical trial in $\mathrm{AD}$ patients. Many of the AD clinical trials currently underway target different pathogenic pathways active in the disease ${ }^{1}$.

Several clinical trials are targeting the reduction of $A \beta$. The rationale stems from predictions based on the amyloid hypothesis, originally proposed by Hardy and Higgins (1992) and updated

\footnotetext{
${ }^{1}$ http://clinicaltrials.gov/ct2/results\%3Fterm=alzheimer\%27s\%26pg=6
}

by Hardy (2006) suggesting that $A \beta$ is a critical causative factor in the disease. Thus, the focus of several clinical trials has been to either reduce production (secretase inhibition) or increase clearance (immunotherapy) of $A \beta$. Unfortunately, most of these promising new approaches have failed in clinical trials (for review, see Mullane and Williams, 2013). Possible reasons for failure include but are not limited to: (1) the targets are not critical for AD pathogenesis and dementia, (2) the single pathway reductionist approach may be insufficient, (3) the treatment is too late (suggesting prevention studies) or, (4) the preclinical animal model was not a predictor of human clinical trials outcomes. In this review we first discuss the canine model of human aging and $\mathrm{AD}$, how dogs are well suited for prevention studies based on established sensitive cognitive tasks and brain pathology measures, and then outcomes of preclinical studies with both single and multiple targets that may predict human clinical trial outcomes.

\section{THE CANINE MODEL OF HUMAN AGING AND ALZHEIMER'S DISEASE}

Some of the most commonly studied animal models of human brain aging are rodents and non-human primates (Gallagher and Rapp, 1997). Other animals, including wolves, bears, cats, and dogs, naturally develop human-like neuropathology (Head et al., 2001). Of these animals, cats and dogs tend to have similar 
living environments to humans (Head et al., 2001). Canines, however, show cognitive decline with age and develop most aspects of neuropathology seen in aged human brain including AD patients (Cummings et al., 1996b; Cotman and Head, 2008). Such neuropathology includes A $\beta$ pathology, reduced brain volume, neuronal loss, and impaired neurogenesis (Head, 2001; Cotman and Head, 2008). In addition to the similar cognitive decline and accumulation of neuropathological hallmarks to humans with $\mathrm{AD}$, drugs exhibit similar pharmacokinetics when administered to dogs or humans [for example statins - (Gerson etal., 1989; Alberts, 1990)], making them an appropriate model for translational studies on therapeutic drugs. Not only are dogs easy to handle due to their long history of domestication, but pet dogs also share similar living conditions and diets to humans (Cummings etal., 1996b; Parker et al., 2004; Axelsson et al., 2013). Canines are highly motivated by food reward when conducting cognitive tests, which makes them cooperative research subjects by reducing or eliminating deprivation protocols for motivation. Thus, this cooperativeness eliminates many physiological stressors that can affect cognitive testing results present in other animal models such as rodents that require food deprivation or cold water for motivation (Blizard et al., 2003). The similar cognitive decline and accumulation of neuropathology to humans makes the canine model of aging useful for translational research on neurodegenerative diseases, especially AD.

\section{COGNITIVE OUTCOME MEASURES FOR PREVENTION STUDIES IN AGING DOGS}

We describe several measures of cognition that are age-sensitive and treatment-sensitive in dogs that can be used as intervention outcome measures to assess different cognitive abilities with analogous tasks in non-human primates and in humans (Table 1). Much like humans, the aging canine shows cognitive decline with various cognitive domains and cortical pathways being differentially affected (Milgram et al., 1994). Dogs show cognitive deficits due to age in tests measuring complex learning, executive function, spatial learning and attention, and memory (Milgram et al., 1994, 2002b; Head et al., 1998a; Cotman et al., 2002; Tapp et al., 2003a,b, 2004b; Christie et al., 2005; Siwak et al., 2005; Studzinski et al., 2006). In addition to cognitive domain variability, individual dogs also show variability in cognitive function as seen in humans (Adams et al., 2000). This variability becomes most apparent in old canines, and using spatial learning and memory tasks, we are able to distinguish three groups of variability: (1) successful agers, (2) impaired dogs whose scores fell two SD above the mean of the young animals, and (3) severely impaired dogs who failed to learn the task (Head et al., 2001). The availability of age-matched animals with and without cognitive deficits allowed researchers to determine which types of neuropathology contribute to individual cognitive impairments in these animals (e.g., Head et al., 1998a).

Several tasks, similar to those used for testing cognition in non-human primates, have been developed to measure cognitive decline in the aging canine (Milgram et al., 1994, 1999, 2002a; Table 1). Such tasks include landmark discrimination, oddity discrimination, object, size and black/white discrimination and reversal tasks, and a spatial memory task. In our laboratory studies using these cognitive tasks, all testing occurs in a modified Wisconsin General Testing Apparatus such that the motor and sensory demands are consistent across tasks (Milgram et al., 1994). For each task, 10-12 trials are given per day and dogs are tested daily until a predetermined criterion level of performance is reached; total error scores are added up across days to provide a measure of learning and/or memory for each animal. These tasks are described in more detail below to illustrate how a test battery can be developed to measure the function of several brain circuits that may be differentially affected by age and/or treatment in aging dogs.

The landmark discrimination task, which measures visuospatial function and allocentric learning, involves presenting dogs with two identical objects, one of which is adjacent to a third object that serves as a landmark (Milgram et al., 1999). Animals are required to recognize that the landmark is an indicator of which object covers the food reward, and selection of the object closest to this landmark by the animal is considered a correct response. The task is made successively more difficult by placing the landmark further away from the object covering the reward. Previous work shows that aged dogs are impaired on the landmark task and show age decrements in their ability to determine how close the landmark is to the correct object (Milgram et al., 1999, 2002a).

The oddity discrimination task measures complex learning, as well as prefrontal cortex function (Cotman et al., 2002). Aged dogs show deficits in oddity discrimination learning (Cotman et al., 2002; Milgram et al., 2002b). In this task, dogs are presented with three objects simultaneously, two of which are identical and a third that is unique. A correct response is indicated when the dog chooses the unique object, resulting in a reward. To prevent a floor effect and detect progressive age decline, the oddity aspect of this task is made successively more difficult. Animals progress through four sets of three objects and each subsequent set contains a unique object, which is more difficult to distinguish from others than the previous set (Milgram et al., 2002b). Interestingly, young dogs can solve this problem by using the strategy of selecting the novel object for each successive set of objects such that error scores plateau; in contrast, aged dogs do not learn a strategy but re-learn each set of objects as a new problem (Cotman et al., 2002; Milgram et al., 2002b).

Tests of object, size and black/white discrimination are administered to measure associative learning ability. Object discrimination involves presenting dogs with two different objects simultaneously with one of the two objects consistently rewarded. Dogs must learn to select the same object each presentation with the left/right position being randomly determined. Similarly, the size discrimination objects differ in size (small/large) and the black/white discrimination task objects differ only in color (black/white; Milgram et al., 2005). Object, size and black/white discrimination are also progressively more difficult for animals to solve given the similarities in the objects increasing. Thus, these three tasks in combination can serve as different test versions (much like in clinical studies in people) to assess longitudinal changes in learning while reducing practice effects (Milgram et al., 2005).

Executive function can be evaluated immediately after discrimination learning has been completed by using the object, size or 


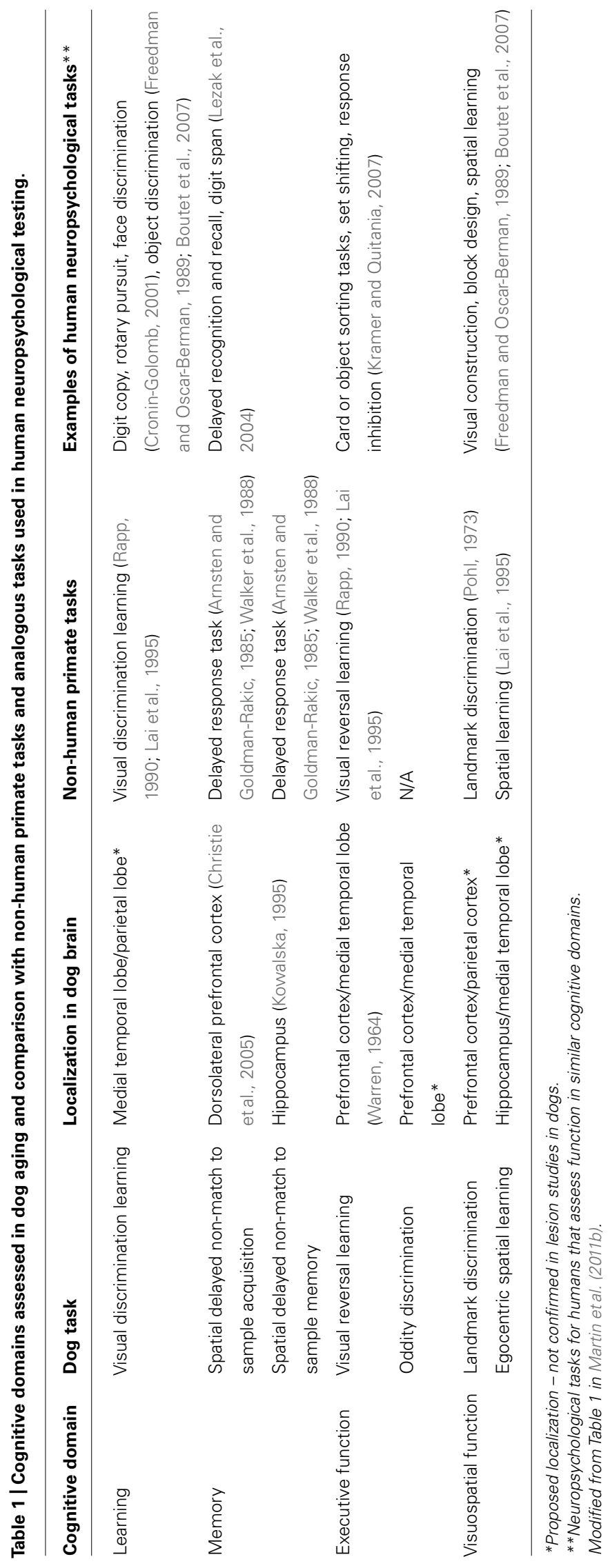


black/white reversal objects. The reversal tasks differ from the original discrimination task in that the positive and negative objects for reward contingencies are reversed after animals have learned the initial discrimination (Milgram et al., 2004, 2005). Reversing the reward contingencies can show perseverative behaviors (persistent choice of previously correct object), which are frontal cortex dependent (Warren, 1964). A subset of the discrimination learning tasks and all reversal learning tasks are age-dependent, with reversal learning being consistently more impaired with age (Milgram etal., 1994, 2004, 2005; Tapp etal., 2004b; Siwak et al., 2005).

Memory also declines with age in dogs. The most useful agesensitive task we have used is a spatial memory task, in which dogs are required to recognize the location of a sample stimulus and then respond to a different location during the test trial. We refer to this as a delayed non-match to position task (DNMP) and it involves showing animals a single object covering a food reward either on the left or right food well. After animals move the object and obtain the reward, the object is withdrawn from sight for a predetermined delay period (e.g., $10 \mathrm{~s}$ ). Subsequently animals are given two identical objects to choose from; one is the same object in the same position as before and one is in a novel position. The correct response is to select the object covering the novel location. Results published in 1995, Head et al. (1995) suggested that the task was age-sensitive. We subsequently developed a three-choice visuospatial working memory task that allows determination of the differential age-dependent strategies (e.g., cognitive or stimulus-dependent strategies) dogs use in solving the problem (Chan etal., 2002). In this task, rather than just the left and right food wells are used but a center well is also included to make the task more difficult. Further, this task shows minimal practice effects in longitudinal studies (Head et al., 2008). We identified the time course of the development of cognitive decline and found that deterioration in spatial ability occurs early in the aging process, between 6 and 7 years of age in dogs (Studzinski et al., 2006).

\section{BEHAVIORAL/FUNCTIONAL OUTCOME MEASURES FOR PREVENTION STUDIES IN DOGS}

In addition to cognitive outcome measures, researchers and veterinarians are interested in measuring functional outcomes. Further, laboratory-based cognitive testing as described above is labor intensive and requires many months to years to obtain data. An open field test can be used to observe the behavioral patterns of animals in an empty room for $10 \mathrm{~min}$. During this task, movement, sniffing, urinating, grooming, rearing, jumping, vocalization, and inactivity are noted (Head and Milgram, 1992; Siwak et al., 2000, 2001). Self-recognition can be evaluated through the mirror test, originally developed for primates (Gallup, 1968; de Veer et al., 2003), by observing the reaction of each animal with a mirror and their reflection. Exploratory behavior of canines can be assessed through a curiosity test in which animals are presented with various novel play objects. During their time with the objects, the amount of time the dogs spend in physical contact with or sitting next to the objects is recorded as well as their frequency of sniffing the objects (Siwak et al., 2001). Social responsiveness of dogs can be gaged through a few different tasks: a human interaction test, silhouette test, and the model dog test. A human interaction test is performed by the presence of a person in the middle of the room and recording the reaction of the dog to that person by measuring the time the dog is in physical contact with the person, time sitting or standing beside the person, and frequency sniffing the person (Head et al., 1997). The silhouette test records the animals frequency of sniffing the front and rear regions of a cardboard silhouette of a dog posted onto a wall (Fox and Weisman, 1970). The model dog test also records the sniffing frequency of the dogs, but this time in response to the presence of a life size model dog in the center of a room (Siwak et al., 2001).

Behavioral patterns in these tasks show age effects as well as differential effects based on the presence of intact/impaired cognition. Siwak et al. (2001) characterized the behavioral profiles of young (2-4 years), aged (9-15 years) cognitively impaired, and aged non-impaired beagles. Young dogs tend to show greater responsiveness to changes in environments such as the addition of novel objects and a person. They also showed greater social responsiveness spending the most time next to or sniffing a person, silhouette, and model dog. Aged unimpaired dogs were still responsive to alterations in environment, but to a lesser degree than the young animals. Additionally, aged unimpaired dogs spent the least amount of time reacting to the mirror during the selfrecognition task. Unlike either the young or aged unimpaired canines, the aged impaired canines were unresponsive to all stimuli presented to the environment and randomly moved about the room in pacing/aimless behavior. However, the aged impaired dogs did spend the most time interacting with the mirror in the self-recognition test (Siwak et al., 2001).

Measures of canine function can also be assessed in a clinical setting (Landsberg and Ruehl, 1997; Landsberg and Araujo, 2005; Landsberg et al., 2012). Clinical measures have been developed consisting of pet dog owner based evaluation of dog behavioral changes (Colle et al., 2000; Pugliese et al., 2006a, 2007; Bosch et al., 2012, 2013; Landsberg et al., 2012) similar to those used in human clinical evaluations, such as the mini mental state exam (MMSE). Although there are different versions of these questionnaires, all appear to be sensitive to the presence of canine cognitive dysfunction (Landsberg et al., 2012). The evaluation consists of items such as walking, posture/emotion of expression, elimination behavior, life rhythm, play behavior, exploratory behavior, learned specific behavior, adaptive capabilities, and interactions with other animals or with owners. The items of individual questionnaires can be used to derive scores that distinguish between normally and pathologically aging dogs. Adult and older dogs generally score worse with these types of evaluation tools, and old dogs show individual variability in terms of the amount of cognitive dysfunction reported (Bosch et al., 2012).

\section{DOG NEUROPATHOLOGY AND OUTCOME MEASURES FOR PREVENTION STUDIES}

Just as canines can exhibit cognitive decline with age similar to aging humans and patients with $\mathrm{AD}$, several human-type neuropathologies have been reported in dogs (Cotman and Head, 2008). In particular, the canine model has long been suggested as an excellent model of $A \beta$ pathogenesis (Wisniewski et al., 1990). 
Several changes observed in the aged canine brain are associated with cognition and are discussed below.

Individuals with $\mathrm{AD}$ show significant cortical and hippocampal atrophy relative to non-demented age matched controls (Alavi et al., 1993; Raz et al., 1998) and losses in brain volume correlate with cognitive decline (Ezekiel et al., 2004; Du et al., 2005). Similar events are seen in aged canines. On cross sectional MR imaging, aging canines show increased cortical atrophy and ventricular widening (Su et al., 1998; Gonzalez-Soriano et al., 2001; Kimotsuki et al., 2005). Ventricular widening over time was observed by MRI in a 3-year longitudinal study (Su et al., 2005). Canine cortical atrophy occurs earliest in the prefrontal cortex and later with age in the hippocampus (Tapp et al., 2004a). As with humans, the more extensive the cortical/hippocampal atrophy seen in aged canines the more pronounced the cognitive deficits (Tapp et al., 2004a; Rofina et al., 2006).

Neuronal loss occurs in human brain aging and could explain the brain volume losses seen in brain imaging (West, 1993; Simic et al., 1997). With normal brain aging, neuronal loss is only seen in the hilus (West, 1993; West et al., 1994), while neuronal loss is much more widespread in individuals with AD (Bobinski et al., 1997; West et al., 2000). Individuals with AD experience neuronal loss in the CA1, CA2, CA4, and subiculum of the hippocampus (Bobinski et al., 1997; West et al., 2000; Price et al., 2001). In aged beagles, the hilus of the dentate gyrus showed fewer neurons compared to younger dogs (Siwak-Tapp et al., 2008). Beagles with fewer neurons in the hilus made significantly more errors when performing the size discrimination task (Siwak-Tapp et al., 2008). Similarly, Pugliese et al. (2007) found that a loss of Purkinje cells in canines correlated with data acquired by questionnaires quantifying behavioral deficits. However, neuronal loss may not account for all of the brain atrophy observed by MR as the loss of neuronal dendritic spines occurs with AD (Knobloch and Mansuy, 2008; Overk and Masliah, 2014) but to our knowledge, there are currently no studies published evaluating similar changes with age in dogs.

While selective neuronal loss may occur with aging, the brain is also able to produce new neurons. The hippocampus, for example, grows new neurons in the subgranular layer (Eriksson et al., 1998). Neurogenesis has been explored in aged beagles using BrdU and doublecortin protein staining methods. Siwak-Tapp et al. (2007) measured neurogenesis in aged beagles using BrdU and found that animals over the age of 13 experienced a significant loss of neurogenesis. Fewer newer BrdU positive neurons was associated with poorer cognitive function in learning and memory and learning ability (Siwak-Tapp et al., 2007).

Neuronal dysfunction could result in abnormal production of critical neurotransmitters in the brain. Thus, one potential target for therapeutics in $\mathrm{AD}$ is to manipulate or restore decreased neurotransmitter levels. Some drugs targeting neurotransmitters are already available as treatments for AD; however, as mentioned earlier; these drugs at best provide only symptomatic relief. Neurotransmitter deficits have not been thoroughly explored in canines. In humans, decreases in specific neurotransmitter systems are associated with aging and AD (Meltzer et al., 1998; Ballard et al., 2005; Schliebs and Arendt, 2006; Rissman et al., 2007). Dogs with $\mathrm{A} \beta$ accumulation in the gyrus proreus possess fewer serotonergic neurons (Bernedo et al., 2009). A decrease in receptor binding of serotonin is seen with age in dogs over 8 years of age (Peremans et al., 2002). Animals with high levels of $A \beta$ in the prefrontal cortex experience a loss of noradrenergic neurons in the locus ceruleus, which is also associated with cognitive dysfunction (Insua et al., 2010). Acetylcholinesterase density is reduced in granule cells of the cerebellum with age (Pugliese et al., 2007). Aged canines experience a loss of gamma-aminobutyric acid interneurons in the prefrontal cortex (Pugliese et al., 2004), as well as the CA1 and dentate gyrus of the hippocampus (Hwang et al., 2008b). Additionally, a loss of glutamic acid decarboxylase 67 neurons in CA1 of the hippocampus is seen in aged canines over 10 years of age (Hwang et al., 2008b). Thus, similar patterns of age-associated neurotransmitter system dysfunction appear in aging dogs and may be a suitable model system in which to develop or test novel neurotransmitter pathway-based interventions. The pathogenic mechanisms underlying neuronal dysfunction, neurotransmitter losses and death may include, e.g., the deposition of $A \beta$, cerebrovascular dysfunction, or oxidative damage.

Beta-amyloid $(A \beta)$ is derived from a longer precursor protein, the amyloid precursor protein (APP). The APP sequence of Canis familiaris has $98 \%$ homology with human $\mathrm{APP}^{2}$ and an identical amino acid sequence (Selkoe et al., 1987; Johnstone et al., 1991). Additionally, $\operatorname{dog} \mathrm{A} \beta$ peptides may undergo the same posttranslational modifications as in humans (Satou et al., 1997; Azizeh et al., 2000). These similarities make canines a viable aging model without the need for genetic modification or overexpression of mutant human proteins (Selkoe et al., 1987).

The $A \beta$ present in canines is ultrastructurally fibrillar and, though more compact deposits may form, it generally aggregates into diffuse plaques (Giaccone et al., 1990; Russell et al., 1992; Uchida et al., 1992; Cummings et al., 1993; Morys et al., 1994; Torp et al., 2000a,b). This type of A $\beta$ deposition most resembles early AD pathology (Morris et al., 1996; Markesbery et al., 2006; Cotman and Head, 2008; Figures 1A,B). Since most AD therapeutics studied today are likely to have a greater affect if applied earlier in the disease progression, the early $\mathrm{AD}$-like pathology canines produce makes them an attractive model for prevention studies (Martin et al., 2011b). As with cognitive decline, AD-like neuropathology has a region specific progression in both humans and canines (Wisniewski et al., 1970; Selkoe et al., 1987; Giaccone et al., 1990; Braak and Braak, 1991; Head et al., 2000; Thal et al., 2002). Though this progression in dogs is similar to that reported in humans, it is not identical. In canines, the accumulation of $\mathrm{A} \beta$ begins in the prefrontal cortex (approximately 8 years at age of onset) and continues to develop with increasing age to include other regions such as the temporal and occipital cortex (Russell etal., 1996; Head et al., 2000; Cotman and Head, 2008). The severity of neuropathology can vary between individual animals but can be linked to the extent of cognitive decline (Cummings etal., 1996a; Head et al., 1998b; Colle et al., 2000; Rofina et al., 2006). For instance, animals who perform worse in reversal learning tasks have greater $A \beta$ pathology in the prefrontal cortex, while those deficient in size discrimination learning show higher amounts of $A \beta$ in the entorhinal

${ }^{2}$ http://www.ensembl.org/Canis_familiaris/ 

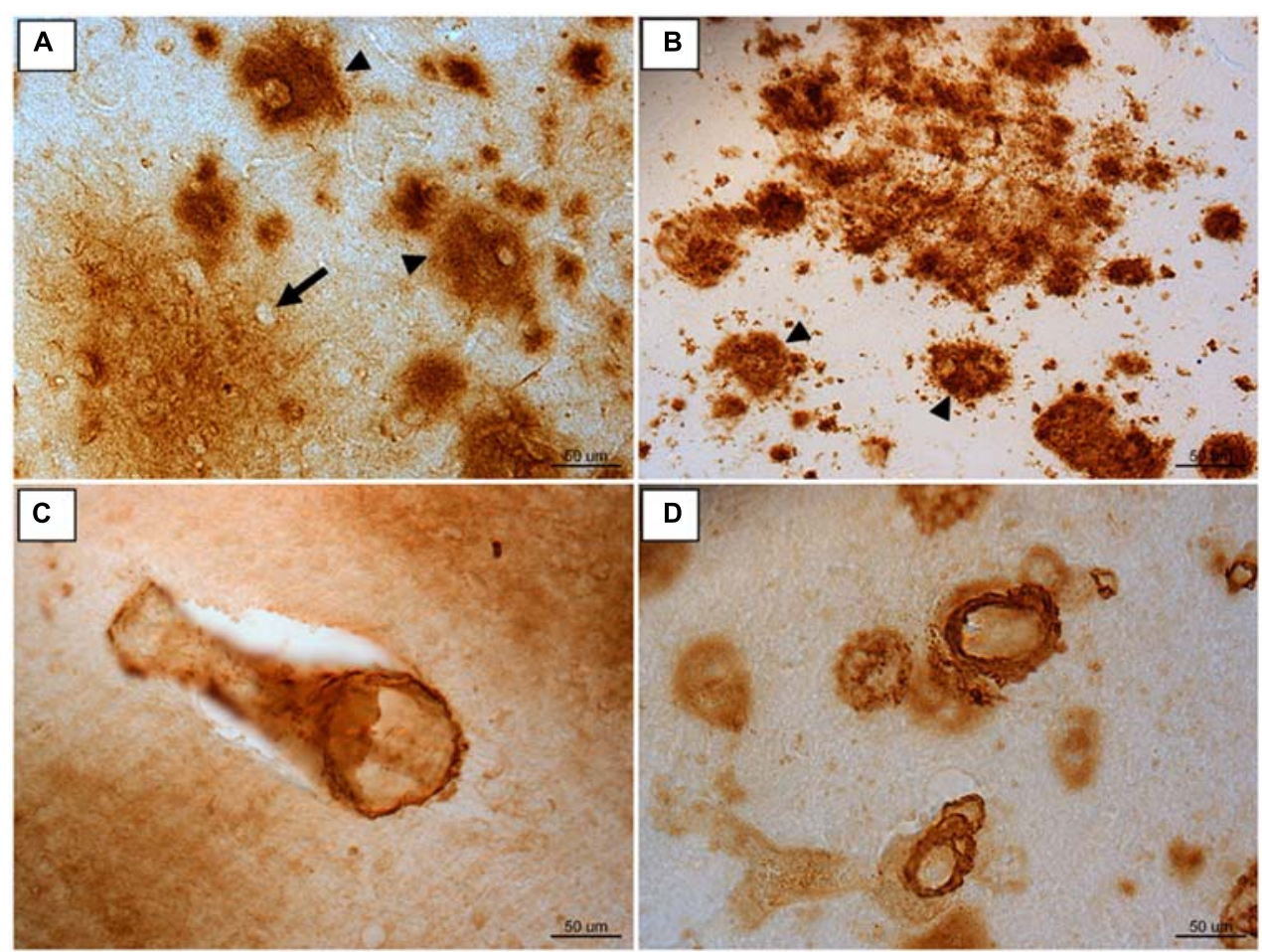

FIGURE 1 | Immunoreactivity for A $\beta$ 1-42 in frontal cortex brain tissue of (A) an aged canine and (B) an aged human. Compact $A \beta$ deposits are similar in humans and canines (arrow head). The outline of an intact neuron enveloped by a diffuse plaque is visible (arrow). A $1-40$ immunoreactivity of cerebral amyloid angiopathy is similar in aged canine occipital cortex (C) and aged human occipital cortex (D). Reproduced from Martin et al. (2011 b). cortex (Cummings etal., 1996a; Head etal., 1998a; Pop et al., 2010b).

$\mathrm{A} \beta$ peptide can also be measured in the cerebrospinal fluid (CSF) of dogs (Sarasa et al., 2013). Measuring CSF A $\beta$ as a ratio of $A \beta 42 / A \beta 40$ is a good predictor of $A \beta$ in the brain in dogs (Head et al., 2010). While brain A $\beta$ increases with age, CSF A $\beta$ decreases with age reflecting the hypothesis that $A \beta$ migrates from the periphery and deposits in the brain with age and AD.

Aside from the fibrillar $\mathrm{A} \beta$ found in diffuse plaques in $\mathrm{AD}$, a smaller, more soluble form of $A \beta$ - oligomeric $A \beta$ - is also seen in the aged dog brain. This more toxic form of $A \beta$ affects synaptic function and can even be found in plaques (Walsh et al., 2002; Kayed et al., 2003; Selkoe, 2008). Higher levels of oligomers are present in canines and humans with increasing age and cognitive decline. The greater the cognitive deficit, the more prevalent oligomers are in the brain (Tomic et al., 2009; Pop et al., 2010a). Similar to fibrillar $A \beta$, oligomeric $A \beta$ can be measured in CSF, where levels are inversely related to levels in the brain (Head et al., 2010).

$\mathrm{A} \beta$ can also aggregate in the cerebral blood vessel walls and cause cerebrovascular pathology (Prior et al., 1996; Attems, 2005; Herzig et al., 2006). This type of deposition is referred to as cerebral amyloid angiopathy (CAA; Figures 1C,D). Typically CAA is composed of the shorter $A \beta$ 1-40 peptide (Wisniewski et al., 1996; Attems, 2005; Herzig et al., 2006). Both humans and canines exhibit CAA pathology, with a particular vulnerability in the occipital cortex (Attems etal., 2005). CAA impairs the blood brain barrier, vascular function, and can cause microhemorrhages (Uchida et al., 1990; Prior et al., 1996; Deane and Zlokovic, 2007). Because of these complications, CAA may contribute to cognitive decline in both humans (Ellis et al., 1996; Rensink et al., 2003; Nicoll et al., 2004; Attems, 2005) and canines (Giaccone et al., 1990; Uchida et al., 1990, 1991; Head, 2013). Much like humans, canines experience microhemorrhages with age (Uchida et al., 1991). These cerebral hemorrhages are present in both animals with and without CAA, but are more common in those with the blood vessel pathology (Uchida et al., 1991). Given the significant overlap of cerebrovascular pathology with $\mathrm{AD}$, the spontaneous accumulation of CAA in dogs also offers as yet, an underappreciated model system to test the effects of cerebrovascular pathology on cognition and $\mathrm{AD}$ neuropathology.

$\mathrm{A} \beta$ deposition may lead to oxidative damage or vice versa, oxidative damage may lead to A $\beta$ (Butterfield, 1997). Ultimately, oxidative damage accumulates with age and can lead to neuronal dysfunction and thus impact cognition (Butterfield et al., 2001). Oxidative damage occurs over time due to the overproduction of reactive oxygen species (ROS) produced primarily by mitochondria. When there is an overabundance of ROS, various mechanisms including production and release of endogenous antioxidants are in place to restore a homeostatic balance. However, ROS overproduction may exceed the levels or production rate of endogenous antioxidants and result in oxidative damage to proteins, lipids, and nucleotides. Oxidative damage can be measured by the amount of protein oxidation (carbonyl 
groups), 4-hydroxynonenal, lipofuscin, lipofuscin-like pigments, and malondialdehyde (lipid peroxidation). Further, 8-hydroxy-2' deoxyguanosine $(8 \mathrm{OHdG})$ can be measured to detect DNA/RNA oxidation.

While oxidative damage occurs with normal aging, it is more pronounced in AD (Smith etal., 1991, 1996, 2000; Ames et al., 1993; Lovell et al., 1999; Montine et al., 2002; Pratico et al., 2002; Butterfield et al., 2007; Lovell and Markesbery, 2008), and similar patterns are seen in canines. In the canine model, there is evidence that ROS production is higher than in younger animals. In mitochondria isolated from aged canine brain, there is an increased production of ROS compared to mitochondria isolated from young animals (Head et al., 2009). Canines also experience an accumulation of carbonyl groups with age (Head et al., 2002; Skoumalova et al., 2003). Lipid peroxidation is exhibited in old dogs, measured by 4-hydroxynonenal (Papaioannou et al., 2001; Rofina et al., 2004, 2006; Hwang et al., 2008a), lipofuscin (Rofina et al., 2006), lipofuscin-like pigments (Papaioannou et al., 2001; Rofina et al., 2004), or malondialdehyde (Head et al., 2002). Increased $8 \mathrm{OHdG}$ in aged canines has also been reported (Rofina etal., 2006; Cotman and Head, 2008). In particular, increased protein oxidation and lipid peroxidation (lipofuscin-like pigment) correlates with cognitive decline in dogs (Skoumalova et al., 2003; Rofina et al., 2004, 2006). Given that canines exhibit age-associated oxidative damage in the brain that correlates with poorer cognition, these animals are suitable to study antioxidant treatment/prevention strategies.

One hallmark AD pathology canines do not produce is NFTs (Selkoe et al., 1987; Russell et al., 1992). While no research to date has observed NFTs in the canine brain, the increased phosphorylation seen at some sites of tau in AD cases also occurs in cognitively impaired canines (Kuroki et al., 1997; Wegiel et al., 1998; Papaioannou et al., 2001; Head et al., 2005; Pugliese et al., 2006b). This lack of NFT pathology could possibly be due to significant differences in the tau protein sequence between canines and humans ${ }^{3}$. However, an advantage to dogs not accumulating NFTs is that they serve as a model that is selective for $A \beta$ pathology and ideally suited for testing interventions that target this toxic protein.

\section{TREATMENT STUDIES IN AGED DOGS AND PREDICTING HUMAN CLINICAL TRIALS}

Several studies have tested therapeutic strategies using the canine model of aging and $\mathrm{AD}$ with both cognitive and neuropathological outcome measures (Table 2). Several of these involve dietary and/or environmental manipulations. One of the earliest studies to develop a treatment for cognitive dysfunction in aged dogs tested an antioxidant-rich diet in combination with behavioral enrichment. The behavioral enrichment included increased exercise, interaction with other dogs, and cognitive enrichment (Cotman etal., 2002; Milgram et al., 2002a, 2004, 2005). The diet included vitamins $\mathrm{E}$ and $\mathrm{C}$, fruits and vegetables, lipoic acid and carnitine. Compared to control animals, those receiving an antioxidant-rich diet committed fewer errors during landmark acquisition and retention tasks (Milgram et al., 2002a) as well as oddity discrimination tasks (Cotman et al., 2002). Treatment

\footnotetext{
${ }^{3}$ http://www.ensembl.org/Canis_familiaris/
}

with an antioxidant diet and behavioral enrichment resulted in improved performance during black and white object discrimination and reversal (Milgram etal., 2005). Pop etal. (2010b) found dogs provided with both behavioral enrichment and an antioxidant diet have an overall reduction in $\mathrm{A} \beta$ pathology across multiple regions of the brain. However, when looking at group treatment effects, only the antioxidant-treated animals had a significant reduction in $\mathrm{A} \beta$ plaque pathology. Additionally, the combination treatment approach of behavioral enrichment and an antioxidant-rich diet in aged canines was unable to reduce existing brain $A \beta$ (Pop etal., 2010b). While plaque load was affected by the dual intervention, soluble and insoluble $A \beta$ 1-40 was not affected, and only soluble levels of $A \beta$ 1-42 were lowered specifically in the prefrontal cortex. A trend toward a significant decrease in oligomers specifically in the parietal cortex was observed in canines receiving the combined treatment (Pop et al., 2010b). Interestingly, the combination group also showed reduced oxidative damage (Opii et al., 2008) with the antioxidant diet group alone showing reduced mitochondrial dysfunction (Head et al., 2009). Further, the behavioral enrichment group, independent of the antioxidant diet treatment showed less neuron loss in the hippocampus (Siwak-Tapp et al., 2008) as well as improved levels of brain derived growth factor (Fahnestock et al., 2010).

Supplemental medium-chain TAG (MCT) increases ketone levels in the brain, and these ketones can in turn be used as an alternative energy source. Pan et al. (2010) measured cognitive effects seen due to this supplement on the landmark discrimination, oddity discrimination, and two choice egocentric spatial learning tasks. Results indicated aged dogs given a diet with MCT supplementation performed better than those receiving a control diet in all tasks (Pan et al., 2010).

In contrast, fewer benefits on cognition were observed in a study using a medical food cocktail (Head et al., 2012). Dogs receiving a combination cocktail containing an extract of turmeric containing 95\% curcuminoids, an extract of green tea containing 50\% epigallocatechin gallate, $\mathrm{N}$-acetyl cysteine, $\mathrm{R}$-alpha lipoic acid and an extract of black pepper containing 95\% piperine exhibited fewer errors compared to control animals during the landmark task indicating improved spatial attention. However, other areas of cognition were unaffected and brain $\mathrm{A} \beta$ remained unchanged (Head et al., 2012).

In 2008, a therapeutic approach that directly targeted $\mathrm{A} \beta$ reduction was explored in which aged beagles were actively immunized with fibrillar $A \beta 1-42$ for 2 years (Immunized - IMM) based upon previous work in transgenic mouse models of $\mathrm{AD}$ (Schenk etal., 1999). This immunotherapy approach led to no improvement in cognitive function, but interestingly a long term maintenance of executive function was noted based on error scores from the size reversal learning task (Head et al., 2008). However, significant benefits to brain pathology were observed in the IMM dogs who showed significantly decreased $A \beta$ plaque load in prefrontal, entorhinal, and occipital cortical regions, as well as reduced CAA (Head etal., 2008). While soluble and insoluble brain $A \beta \quad 1-40$ and 42 significantly decreased in treated canines, there was no significant reduction in soluble oligomers. This study suggests that reducing 


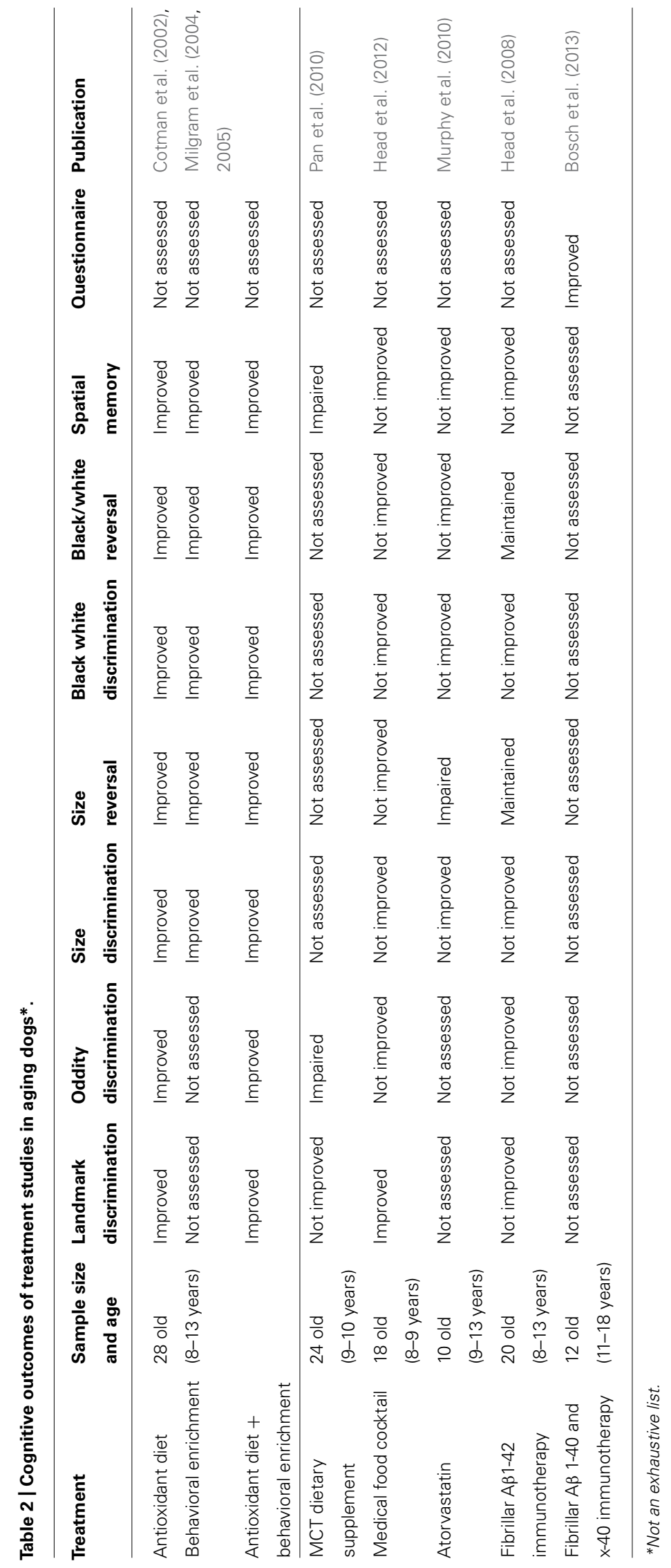


or eliminating pre-existing $A \beta$ in aging dogs is not sufficient to improve cognition.

Outcomes from the longitudinal dog vaccination study are similar to reports of the clinical trial in patients with $\mathrm{AD}$ where no differences between antibody responders and placebo groups on several cognitive and disability scales was observed. A small number of patients enrolled in the AN1792 study have come to autopsy and show $A \beta$ plaque reduction without any effect on the extent of NFT or CAA (Nicoll et al., 2003; Ferrer et al., 2004; Masliah et al., 2005). Further, the frontal cortex showed the largest response to immunotherapy (Masliah et al., 2005), which is similar to our observations in the dog. The most recent autopsy study of eight patients that were in the AN1792 study further confirm reduced $\mathrm{A} \beta$ pathology in response to treatment, 5 years after the last injection (Holmes et al., 2008). However, reduction of brain A $\beta$ did not slow disease progression and seven of eight patients had severe end stage dementia prior to death. (Gilman et al., 2005). Interestingly, a composite score of a neuropsychological test battery indicated "less worsening" of decline in antibody responders after 12 months and an improvement in the memory domain (Gilman et al., 2005).

Bosch et al. (2013) recently showed benefits of an active fibrillar $A \beta_{40}$ and $A \beta_{x-40}$ combination vaccine on cognition in aged housed beagles and pet dogs treated for 51 days. Over the course of treatment, cognitive evaluations by questionnaire were given at 31 days post treatment and at the end of treatment. Immunized animals showed a significant improvement in cognitive evaluation scores at both 31 and 51 days post treatment compared to pre-immunized scores (Bosch et al., 2013). Differences in the formulation, the outcome measures or the source of animals may explain the positive effects in the Bosch study compared with the previous beagle vaccine studies.

Several studies in the aged dog have tested the effects of drugs already approved for use in humans, with novel applications to brain aging. For example, several cross-sectional or casecontrol epidemiological studies revealed a striking link between cholesterol-lowering drugs (e.g., statins and others) and a 20-70\% reduction in risk of developing AD (Jick et al., 2000; Wolozin et al., 2000, 2007; Hajjar et al., 2002; Rockwood et al., 2002; Rodriguez et al., 2002; Zamrini et al., 2004; Dufouil et al., 2005). Modest cognitive benefits have been reported in preliminary $\mathrm{AD}$ clinical trials with simvastatin (Simons et al., 2002) and atorvastatin (Sparks et al., 2005a,b, 2006a,b). In particular, AD patients with mild to moderate dementia who were treated with $80 \mathrm{mg} /$ day atorvastatin had significantly improved scores on one measure of cognition Alzheimer's Disease Assessment Scale-Cognitive subscale (ADASCog) at 6 months of treatment, with smaller non-significant benefits at 12 months (Sparks et al., 2005b).

Statins may reduce the risk of incident $\mathrm{AD}$ through the prevention of $\mathrm{A} \beta$ production (Simons et al., 1998; Hartmann, 2001). In rodent models, treatment with inhibitors of 3-hydroxy-3methylglutaryl coenzyme A (HMG-CoA) or statins reduces A $\beta$ (Petanceska et al., 2002). However, rodents respond to statin treatment by massively upregulating HMG-CoA reductase levels (Fears et al., 1980; Alberts, 1990; Todd and Goa, 1990; Thelen et al., 2006). To compensate, long-term studies in rodent often employ physiologically excessive doses, making it difficult to translate the results of these studies into human trials.
The dog model is particularly useful to study chronic statin treatment, given similarities with humans in terms of dose requirements, responsiveness, drug handling, and metabolism (Gerson et al., 1989; Alberts, 1990). For example, 12 dogs were treated with $80 \mathrm{mg} /$ day of atorvastatin for 14.5 months (Murphy et al., 2010). Peripheral levels of cholesterol, low density lipoproteins, triglycerides and high density lipoproteins were reduced in treated dogs. Surprisingly, a transient impairment in reversal learning was observed, suggesting prefrontal dysfunction. Spatial memory remained unchanged up to over a year of treatment. The lack of cognitive benefits of treatment was also reflected by a lack of reduction in plasma, $\mathrm{CSF}$, and brain $\mathrm{A} \beta$. Interestingly, BACE1 protein level was decreased in the brains of atorvastatin-treated dogs. This intriguing outcome may suggest that statins might be more useful to prevent the production of $A \beta$ through lowering BACE1 if started in animals in middle age, consistent with human studies indicating that middle-aged individuals using statins are protected from AD.

More recent work on the brain from statin-treated aged dogs suggests that additional benefits of atorvastatin include reducing oxidative damage and upregulating endogenous protective pathways. Thus, statins may have multiple benefits to the brain by affecting several pathways impaired by aging (Barone et al., 2011, 2012; Martin et al., 2011a; Butterfield et al., 2012). Aged dogs are a unique model that may provide novel insights and translational data to predict outcomes of statin use in human clinical trials.

\section{SUMMARY}

Aged dogs capture many features of human aging and AD including cognitive decline and neuropathology. Canine studies show that multi-targeted approaches may be more beneficial than single pathway manipulations (e.g., antioxidants combined with behavioral enrichment vs. $A \beta$ vaccine). Further, prevention studies could be accomplished in a 5-year period to test the effects of an intervention on the development of cognitive decline and neuropathology. Interestingly, an immunotherapy study in aged dogs illustrates the predictive validity of using this model system as aged dogs did not show cognitive improvements with an $A \beta$ vaccine despite showing significant brain $A \beta$ reductions, much like reports in the AD clinical trial. The canine model has numerous advantages as described above, however, systematic cognitive testing can be a lengthy and costly (given per diem rates) process and requires significant technical support. Still, the canine model should be considered an option since it is less involved and costly than a human clinical prevention study. Overall, using the dog as a preclinical model for testing preventive approaches for $\mathrm{AD}$ may be a useful step that complements work in rodents and non-human primates.

\section{ACKNOWLEDGMENTS}

Research reported in this manuscript was supported by NIH/NIA R01AG032550 to Elizabeth Head. The project described was also supported by the National Center for Advancing Translational Sciences, UL1TR000117 to Paulina R. Davis. The content is solely the responsibility of the authors and does not necessarily represent the official views of the National Institutes of Health. We thank Paula Thomason for her careful editing of the manuscript. 


\section{REFERENCES}

Adams, B., Chan, A., Callahan, H., and Milgram, N. W. (2000). The canine as a model of human cognitive aging: recent developments. Prog. Neuropsychopharmacol. Biol. Psychiatry 24, 675-692. doi: 10.1016/S0278-5846(00)00101-9

Aisen, P. S., Cummings, J., and Schneider, L. S. (2012). Symptomatic and nonamyloid/tau based pharmacologic treatment for Alzheimer disease. Cold Spring Harb. Perspect. Med. 2, a006395. doi: 10.1101/cshperspect.a006395

Alavi, A., Newberg, A. B., Souder, E., and Berlin, J. A. (1993). Quantitative analysis of PET and MRI data in normal aging and Alzheimer's disease: atrophy weighted total brain metabolism and absolute whole brain metabolism as reliable discriminators. J. Nucl. Med. 34, 1681-1687.

Alberts, A. W. (1990). Lovastatin and simvastatin - inhibitors of HMG CoA reductase and cholesterol biosynthesis. Cardiology 77, 14-21. doi: 10.1159/000174688

Ames, B. N., Shigenaga, M. K., and Hagen, T. M. (1993). Oxidants, antioxidants, and the degenerative diseases of aging. Proc. Natl. Acad. Sci. U.S.A. 90, 7915-7922. doi: 10.1073/pnas.90.17.7915

Arnsten, A. F. T., and Goldman-Rakic, P. S. (1985). Alpha 2-adrenergic mechanisms in prefrontal cortex associated with cognitive decline in aged nonhuman primates. Science 230, 1273-1276. doi: 10.1126/science.2999977

Attems, J. (2005). Sporadic cerebral amyloid angiopathy: pathology, clinical implications, and possible pathomechanisms. Acta Neuropathol. 110, 345-359. doi: 10.1007/s00401-005-1074-9

Attems, J., Jellinger, K. A., and Lintner, F. (2005). Alzheimer's disease pathology influences severity and topographical distribution of cerebral amyloid angiopathy. Acta Neuropathol. 110, 222-231. doi: 10.1007/s00401-005-1064-y

Axelsson, E., Ratnakumar, A., Arendt, M. L., Maqbool, K., Webster, M. T., Perloski, M., et al. (2013). The genomic signature of dog domestication reveals adaptation to a starch-rich diet. Nature 495, 360-364. doi: 10.1038/nature11837

Azizeh, B. Y., Head, E., Ibrahim, M. A., Torp, R., Tenner, A. J., Kim, R. C. et al. (2000). Molecular dating of senile plaques in the brains of individuals with down syndrome and in aged dogs. Exp. Neurol. 163, 111-122. doi: 10.1006/exnr.2000.7359

Ballard, C. G., Greig, N. H., Guillozet-Bongaarts, A. L., Enz, A., and Darvesh S. (2005). Cholinesterases: roles in the brain during health and disease. Curr Alzheimer Res. 2, 307-318. doi: 10.2174/1567205054367838

Barone, E., Cenini, G., Di Domenico, F., Martin, S., Sultana, R., Mancuso, C., et al. (2011). Long-term high-dose atorvastatin decreases brain oxidative and nitrosative stress in a preclinical model of Alzheimer disease: a novel mechanism of action. Pharmacol. Res. 63, 172-180. doi: 10.1016/j.phrs.2010.12.007

Barone, E., Mancuso, C., Di Domenico, F., Sultana, R., Murphy, M. P., Head, E., et al. (2012). Biliverdin reductase-A: a novel drug target for atorvastatin in a dog pre-clinical model of Alzheimer disease. J. Neurochem. 120, 135-146. doi 10.1111/j.1471-4159.2011.07538.x

Bernedo, V., Insua, D., Suarez, M. L., Santamarina, G., Sarasa, M., and Pesini, P. (2009). $\beta$-amyloid cortical deposits are accompanied by the loss of serotonergic neurons in the dog. J. Comp. Neurol. 513, 417-429. doi: 10.1002/cne.21985

Blizard, D. A., Klein, L. C., Cohen, R., and McClearn, G. E. (2003). A novel mousefriendly cognitive task suitable for use in aging studies. Behav. Genet. 33, 181-189. doi: 10.1023/A:1022510119598

Bobinski, M., Wegiel, J., Tarnawski, M., Bobinski, M., Reisberg, B., de Leon, M. J., et al. (1997). Relationships between regional neuronal loss and neurofibrillary changes in the hippocampal formation and duration and severity of Alzheimer disease. J. Neuropathol. Exp. Neurol. 56, 414-420. doi: 10.1097/00005072-199704000-00010

Bosch, M. N., Gimeno-Bayon, J., Rodriguez, M. J., Pugliese, M., and Mahy, N. (2013). Rapid improvement of canine cognitive dysfunction with immunotherapy designed for Alzheimer's disease. Curr. Alzheimer Res. 10, 482-493. doi: $10.2174 / 15672050113109990129$

Bosch, M. N., Pugliese, M., Gimeno-Bayon, J., Rodriguez, M. J., and Mahy, N. (2012). Dogs with cognitive dysfunction syndrome: a natural model of Alzheimer's disease. Curr. Alzheimer Res. 9, 298-314. doi: 10.2174/1567205128001 07546

Boutet, I., Milgram, N. W., and Freedman, M. (2007). Cognitive decline and human (Homo sapiens) aging: an investigation using a comparative neuropsychological approach. J. Comp. Psychol. 121, 270-281. doi: 10.1037/0735-7036.121. 3.270

Braak, H., and Braak, E. (1991). Neuropathological stageing of Alzheimer-related changes. Acta Neuropathol. 82, 239-259. doi: 10.1007/BF00308809
Butterfield, D. A. (1997). $\beta$-Amyloid-associated free radical oxidative stress and neurotoxicity: implications for Alzheimer's disease. Chem. Res. Toxicol. 10, 495506. doi: 10.1021/tx960130e

Butterfield, D. A., Barone, E., Di Domenico, F., Cenini, G., Sultana, R., Murphy, M. P., et al. (2012). Atorvastatin treatment in a dog preclinical model of Alzheimer's disease leads to up-regulation of haem oxygenase- 1 and is associated with reduced oxidative stress in brain. Int. J. Neuropsychopharmacol. 15, 981-987. doi: 10.1017/S1461145711001118

Butterfield, D. A., Drake, J., Pocernich, C., and Castegna, A. (2001). Evidence of oxidative damage in Alzheimer's disease brain: central role for amyloid $\beta$-peptide. Trends Mol. Med. 7, 548-554. doi: 10.1016/S1471-4914(01)02173-6

Butterfield, D. A., Reed, T., Newman, S. F., and Sultana, R. (2007). Roles of amyloid $\beta$-peptide-associated oxidative stress and brain protein modifications in the pathogenesis of Alzheimer's disease and mild cognitive impairment. Free Radic. Biol. Med. 43, 658-677. doi: 10.1016/j.freeradbiomed.2007.05.037

Chan, A. D., Nippak, P. M., Murphey, H., Ikeda-Douglas, C. J., Muggenburg, B., Head, E., et al. (2002). Visuospatial impairments in aged canines (Canis familiaris): the role of cognitive-behavioral flexibility. Behav. Neurosci. 116, 443-454. doi: 10.1037/0735-7044.116.3.443

Christie, L. A., Studzinski, C. M., Araujo, J. A., Leung, C. S., Ikeda-Douglas, C. J., Head, E., et al. (2005). A comparison of egocentric and allocentric age-dependent spatial learning in the beagle dog. Prog. Neuropsychopharmacol. Biol. Psychiatry 29, 361-369. doi: 10.1016/j.pnpbp.2004.12.002

Colle, M.-A., Hauw, J.-J., Crespeau, F., Uchiara, T., Akiyama, H., Checler, F., et al. (2000). Vascular and parenchymal Ab deposition in the aging dog: correlation with behavior. Neurobiol. Aging 21, 695-704. doi: 10.1016/S0197-4580(00) 00113-5

Cotman, C. W., and Head, E. (2008). The canine (dog) model of human aging and disease: dietary, environmental and immunotherapy approaches. J. Alzheimers Dis. 15, 685-707.

Cotman, C. W., Head, E., Muggenburg, B. A., Zicker, S., and Milgram, N. W. (2002). Brain aging in the canine: a diet enriched in antioxidants reduces cognitive dysfunction. Neurobiol. Aging 23, 809-818. doi: 10.1016/S0197-4580(02)00073-8 Cronin-Golomb, A. (2001). "Color vision, object recognition, and spatial localization in aging and Alzheimer's disease," in Functional Neurobiology of Aging, eds P. R. Hof and C. V. Mobbs (San Diego: Academic Press), 517-529.

Cummings, B. J., Head, E., Afagh, A. J., Milgram, N. W., and Cotman, C. W. (1996a). $\beta$-amyloid accumulation correlates with cognitive dysfunction in the aged canine. Neurobiol. Learn. Mem. 66, 11-23. doi: 10.1006/nlme.1996.0039

Cummings, B. J., Head, E., Ruehl, W., Milgram, N. W., and Cotman, C. W. (1996b). The canine as an animal model of human aging and dementia. Neurobiol. Aging 17, 259-268. doi: 10.1016/0197-4580(95)02060-8

Cummings, B. J., Su, J. H., Cotman, C. W., White, R., and Russell, M. J. (1993). $\beta$-amyloid accumulation in aged canine brain: a model of plaque formation in Alzheimer's disease. Neurobiol. Aging 14, 547-560. doi: 10.1016/01974580(93)90038-D

Deane, R., and Zlokovic, B. V. (2007). Role of the blood-brain barrier in the pathogenesis of Alzheimer's disease. Curr. Alzheimer Res. 4, 191-197. doi: $10.2174 / 156720507780362245$

de Veer, M. W., Gallup, G. G. Jr., Theall, L. A., van den Bos, R., and Povinelli, D. J. (2003). An 8-year longitudinal study of mirror self-recognition in chimpanzees (Pan troglodytes). Neuropsychologia 41, 229-234. doi: 10.1016/S00283932(02)00153-7

Du, A. T., Schuff, N., Chao, L. L., Kornak, J., Ezekiel, F., Jagust, W. J., et al. (2005). White matter lesions are associated with cortical atrophy more than entorhinal and hippocampal atrophy. Neurobiol. Aging 26, 553-559. doi: 10.1016/j.neurobiolaging.2004.05.002

Dufouil, C., Richard, F., Fievet, N., Dartigues, J. F., Ritchie, K., Tzourio, C., et al. (2005). APOE genotype, cholesterol level, lipid-lowering treatment, and dementia: the Three-City Study. Neurology 64, 1531-1538. doi: 10.1212/01.WNL.0000160114.42643.31

Ellis, R. J., Olichney, J. M., Thal, L. J., Mirra, S. S., Morris, J. C., Beekly, D., et al. (1996). Cerebral amyloid angiopathy in the brains of patients with Alzheimer's disease: the CERAD experience, Part, X. V. Neurology 46, 1592-1596. doi: 10.1212/WNL.46.6.1592

Eriksson, P. S., Perfilieva, E., Bjork-Eriksson, T., Alborn, A. M., Nordborg, C., Peterson, D. A., et al. (1998). Neurogenesis in the adult human hippocampus. Nat. Med. 4, 1313-1317. doi: 10.1038/3305 
Ezekiel, F., Chao, L., Kornak, J., Du, A. T., Cardenas, V., Truran, D., et al. (2004). Comparisons between global and focal brain atrophy rates in normal aging and Alzheimer disease: boundary shift integral versus tracing of the entorhinal cortex and hippocampus. Alzheimer Dis. Assoc. Disord. 18, 196-201.

Fahnestock, M., Marchese, M., Head, E., Pop, V., Michalski, B., Milgram, W. N., et al. (2010). BDNF increases with behavioral enrichment and an antioxidant diet in the aged dog. Neurobiol. Aging 33, 546-554. doi: 10.1016/j.neurobiolaging.2010.03.019

Fears, R., Richards, D. H., and Ferres, H. (1980). The effect of compactin, a potent inhibitor of 3-hydroxy-3-methylglutaryl co-enzyme-A reductase activity, on cholesterogenesis and serum cholesterol levels in rats and chicks. Atherosclerosis 35, 439-449. doi: 10.1016/0021-9150(80)90185-9

Ferrer, I., Boada Rovira, M., Sanchez Guerra, M. L., Rey, M. J., and CostaJussa, F. (2004). Neuropathology and pathogenesis of encephalitis following amyloid- $\beta$ immunization in Alzheimer's disease. Brain Pathol. 14, 11-20. doi 10.1111/j.1750-3639.2004.tb00493.x

Fox, M. W., and Weisman, R. (1970). Development of responsiveness to a social releaser in the dog: effects of age and hunger. Dev. Psychobiol. 2, 277-280. doi: $10.1002 /$ dev.420020414

Freedman, M., and Oscar-Berman, M. (1989). Spatial and visual learning deficits in Alzheimer's disease and Parkinson's disease. Brain Cogn. 11, 114-126. doi: 10.1016/0278-2626(89)90009-2

Gallagher, M., and Rapp, P. R. (1997). The use of animal models to study the effects of aging on cognition. Annu. Rev. Psychol. 48, 339-370. doi 10.1146/annurev.psych.48.1.339

Gallup, G. G. Jr. (1968). Mirror-image stimulation. Psychological. Bull. 70, 782-793. doi: $10.1037 / \mathrm{h} 0026777$

Gerson, R. J., MacDonald, J. S., Alberts, A. W., Kornbrust, D. J., Majka, J. A., Stubbs, R. J., et al. (1989). Animal safety and toxicology of simvastatin and related hydroxy-methylglutaryl-coenzyme a reductase inhibitors. Am. J. Med. 87, 28S38S. doi: 10.1016/S0002-9343(89)80596-0

Giaccone, G., Verga, L., Finazzi, M., Pollo, B., Tagliavini, F., Frangione, B., et al. (1990). Cerebral preamyloid deposits and congophilic angiopathy in aged dogs. Neurosci. Lett. 114, 178-183. doi: 10.1016/0304-3940(90)90068-K

Gilman, S., Koller, M., Black, R. S., Jenkins, L., Griffith, S. G., Fox, N. C., etal. (2005). Clinical effects of $A \beta$ immunization (AN1792) in patients with AD in an interrupted trial. Neurology 64, 1553-1562. doi: 10.1212/01.WNL.0000159740.16984.3C

Gonzalez-Soriano, J., Marin Garcia, P., Contreras-Rodriguez, J., Martinez-Sainz, P., and Rodriguez-Veiga, E. (2001). Age-related changes in the ventricular system of the dog brain. Ann. Anat. 183, 283-291. doi: 10.1016/S0940-9602(01)80236-3

Hajjar, I., Schumpert, J., Hirth, V., Wieland, D., and Eleazer, G. P. (2002). The impact of the use of statins on the prevalence of dementia and the progression of cognitive impairment. J. Gerontol. A Biol. Sci. Med. Sci. 57, M414-M418. doi: 10.1093/gerona/57.7.M414

Hardy, J. (2006). Alzheimer's disease: the amyloid cascade hypothesis: an update and reappraisal. J. Alzheimers Dis. 9(Suppl. 3), 151-153.

Hardy, J. A., and Higgins, G. A. (1992). Alzheimer's disease: the amyloid cascade hypothesis. Science 256, 184-185. doi: 10.1126/science.1566067

Hartmann, T. (2001). Cholesterol, A $\beta$ and Alzheimer's disease. Trends Neurosci. 24 (Suppl. 11), S45-S48. doi: 10.1016/S0166-2236(01)00008-X

Head, E. (2001). Brain aging in dogs: parallels with human brain aging and alzheimer's disease. Vet. Ther. 2, 247-260.

Head, E. (2013). A canine model of human aging and Alzheimer's disease. Biochim. Biophys. Acta 1832, 1384-1389. doi: 10.1016/j.bbadis.2013.03.016

Head, E., Callahan, H., Cummings, B. J., Cotman, C. W., Ruehl, W. W., Muggenberg, B. A., et al. (1997). Open field activity and human interaction as a function of age and breed in dogs. Physiol. Behav. 62, 963-971. doi: 10.1016/S0031-9384(97)00198-4

Head, E., Callahan, H., Muggenburg, B. A., Cotman, C. W., and Milgram, N. W. (1998a). Visual-discrimination learning ability and $\beta$-amyloid accumulation in the dog. Neurobiol. Aging 19, 415-425. doi: 10.1016/S0197-4580(98) 00084-0

Head, E., McCleary, R., Hahn, F., Milgram, N. W., and Cotman, C. W. (1998b). "Predicting the presence and location of amyloid deposition in a canine model of human aging and dementia using logistic regression analyses," Proceedings of the sixth International Conference on Alzheimer's Disease and Related Disorders, Amsterdam, Holland.
Head, E., Liu, J., Hagen, T. M., Muggenburg, B. A., Milgram, N. W., Ames, B. N., et al. (2002). Oxidative damage increases with age in a canine model of human brain aging. J. Neurochem. 82, 375-381. doi: 10.1046/j.1471-4159.2002.00969.x

Head, E., McCleary, R., Hahn, F. F., Milgram, N. W., and Cotman, C. W. (2000). Region-specific age at onset of $\beta$-amyloid in dogs. Neurobiol. Aging 21, 89-96. doi: 10.1016/S0197-4580(00)00093-2

Head, E., Mehta, R., Hartley, J., Kameka, M., Cummings, B. J., Cotman, C. W., et al. (1995). Spatial learning and memory as a function of age in the dog. Behav. Neurosci. 109, 851-858. doi: 10.1037/0735-7044.109.5.851

Head, E., and Milgram, N. W. (1992). Changes in spontaneous behavior in the dog following oral administration of L-deprenyl. Pharmacol. Biochem. Behav. 43, 749-757. doi: 10.1016/0091-3057(92)90404-4

Head, E., Milgram, N. W., and Cotman, C. W. (2001). "Neurobiological models of aging in the dog and other vertebrate species," in Functional Neurobiology of Aging, eds P. Hof and C. Mobbs (San Diego: Academic Press), 457-468.

Head, E., Moffat, K., Das, P., Sarsoza, F., Poon, W. W., Landsberg, G., et al. (2005). $\beta$-Amyloid deposition and tau phosphorylation in clinically characterized aged cats. Neurobiol. Aging 26, 749-763. doi: 10.1016/j.neurobiolaging.2004.06.015

Head, E., Murphey, H. L., Dowling, A. L., McCarty, K. L., Bethel, S. R., Nitz, J. A., et al. (2012). A combination cocktail improves spatial attention in a canine model of human aging and Alzheimer's disease. J. Alzheimers Dis. 32, 1029-1042. doi: 10.3233/JAD-2012-120937

Head, E., Nukala, V. N., Fenoglio, K. A., Muggenburg, B. A., Cotman, C. W., and Sullivan, P. G. (2009). Effects of age, dietary, and behavioral enrichment on brain mitochondria in a canine model of human aging. Exp. Neurol. 220, 171-176. doi: 10.1016/j.expneurol.2009.08.014

Head, E., Pop, V., Sarsoza, F., Kayed, R., Beckett, T. L., Studzinski, C. M., et al. (2010). Amyloid- $\beta$ peptide and oligomers in the brain and cerebrospinal fluid of aged canines. J. Alzheimers Dis. 20, 637-646. doi: 10.3233/JAD-2010-1397

Head, E., Pop, V., Vasilevko, V., Hill, M., Saing, T., Sarsoza, F., et al. (2008). A two-year study with fibrillar $\beta$-amyloid $(\mathrm{A} \beta)$ immunization in aged canines: effects on cognitive function and brain A $\beta$. J. Neurosci. 28, 3555-3566. doi: 10.1523/JNEUROSCI.0208-08.2008

Herzig, M. C., Van Nostrand, W. E., and Jucker, M. (2006). Mechanism of cerebral $\beta$-amyloid angiopathy: murine and cellular models. Brain Pathol. 16, 40-54. doi: 10.1111/j.1750-3639.2006.tb00560.x

Holmes, C., Boche, D., Wilkinson, D., Yadegarfar, G., Hopkins, V., Bayer, A., et al. (2008). Long-term effects of A $\beta 42$ immunisation in Alzheimer's disease: followup of a randomised, placebo-controlled phase I trial. Lancet 372, 216-223. doi: 10.1016/S0140-6736(08)61075-2

Hwang, I. K., Yoon, Y. S., Yoo, K. Y., Li, H., Choi, J. H., Kim, D. W., et al. (2008a). Differences in lipid peroxidation and $\mathrm{Cu}, \mathrm{Zn}$-Superoxide dismutase in the hippocampal CA1 region between adult and aged dogs. J. Vet. Med. Sci. 70, 273-277. doi: 10.1292/jvms.70.273

Hwang, I. K., Yoon, Y. S., Yoo, K. Y., Li, H., Sun, Y., Choi, J. H., et al. (2008b). Sustained expression of parvalbumin immunoreactivity in the hippocampal CA1 region and dentate gyrus during aging in dogs. Neurosci. Lett. 434, 99-103. doi: 10.1016/j.neulet.2008.01.035

Insua, D., Suarez, M. L., Santamarina, G., Sarasa, M., and Pesini, P. (2010). Dogs with canine counterpart of Alzheimer's disease lose noradrenergic neurons. Neurobiol. Aging 31, 625-635. doi: 10.1016/j.neurobiolaging.2008.05.014

Jick, H., Zornberg, G. L., Jick, S. S., Seshadri, S., and Drachman, D. A. (2000). Statins and the risk of dementia. Lancet 356, 1627-1631. doi: 10.1016/S01406736(00)03155-X

Johnstone, E. M., Chaney, M. O., Norris, F. H., Pascual, R., and Little, S. P. (1991). Conservation of the sequence of the Alzheimer's disease amyloid peptide in dog, polar bear and five other mammals by cross-species polymerase chain reaction analysis. Brain Res. Mol. Brain Res. 10, 299-305. doi: 10.1016/0169-328X(91)90088-F

Kayed, R., Head, E., Thompson, J. L., McIntire, T. M., Milton, S. C., Cotman, C. W., et al. (2003). Common structure of soluble amyloid oligomers implies common mechanism of pathogenesis. Science 300, 486-489. doi: 10.1126/science.1079469

Kimotsuki, T., Nagaoka, T., Yasuda, M., Tamahara, S., Matsuki, N., and Ono, K. (2005). Changes of magnetic resonance imaging on the brain in beagle dogs with aging. J. Vet. Med. Sci. 67, 961-967. doi: 10.1292/jvms.67.961

Knobloch, M., and Mansuy, I. M. (2008). Dendritic spine loss and synaptic alterations in Alzheimer's disease. Mol. Neurobiol. 37, 73-82. doi: 10.1007/s12035008-8018-z 
Kowalska, D. M. (1995). Effects of hippocampal lesions on spatial delayed responses in dog. Hippocampus 5, 363-370. doi: 10.1002/hipo.450050409

Kramer, J. H., and Quitania, L. (2007). "Bedside frontal lobe testing," in The Human Frontal Lobes, 3rd Edn, eds B. L. Miller and J. L. Cummings (New York: The Guilford Press), 279-291.

Kuroki, K., Uchida, K., Kiatipattanasakul, W., Nakamura, S., Yamaguchi, R., Nakayama, H., etal. (1997). Immunohistochemical detection of tau proteins in various non-human animal brains. Neuropathology 17, 174-180. doi: 10.1111/j.1440-1789.1997.tb00034.x

Lai, Z. C., Moss, M. B., Killiany, R. J., Rosene, D. L., and Herndon, J. G. (1995). Executive system dysfunction in the aged monkey: spatial and object reversal learning. Neurobiol. Aging 16, 947-954. doi: 10.1016/0197-4580(95)02014-4

Landsberg, G., and Araujo, J. A. (2005). Behavior problems in geriatric pets. Vet. Clin. North Am. Small Anim. Pract. 35, 675-698. doi: 10.1016/j.cvsm.2004.12.008

Landsberg, G., and Ruehl, W. (1997). Geriatric behavioral problems. Vet. Clin. North Am. Small Anim. Pract. 27, 1537-1559.

Landsberg, G. M., Nichol, J., and Araujo, J. A. (2012). Cognitive dysfunction syndrome: a disease of canine and feline brain aging. Vet. Clin. North Am. Small Anim. Pract. 42, 749-768. doi: 10.1016/j.cvsm.2012.04.003

Lezak, M. D., Howieson, D. B., and Loring, D. W. (2004). Neuropsychological Assessment. 4th Edn. New York: Oxford University Press.

Lovell, M. A., Gabbita, S. P., and Markesbery, W. R. (1999). Increased DNA oxidation and decreased levels of repair products in Alzheimer's disease ventricular CSF. $J$. Neurochem. 72, 771-776. doi: 10.1046/j.1471-4159.1999.0720771.x

Lovell, M. A., and Markesbery, W. R. (2008). Oxidatively modified RNA in mild cognitive impairment. Neurobiol. Dis. 29, 169-175. doi: 10.1016/j.nbd.2007.07.030

Markesbery, W. R., Schmitt, F. A., Kryscio, R. J., Davis, D. G., Smith, C. D., and Wekstein, D. R. (2006). Neuropathologic substrate of mild cognitive impairment. Arch. Neurol. 63, 38-46. doi: 10.1001/archneur.63.1.38

Martin, S. B., Cenini, G., Barone, E., Dowling, A. L., Mancuso, C., Butterfield, D. A., et al. (2011a). Coenzyme Q10 and cognition in atorvastatin treated dogs. Neurosci. Lett. 501, 92-95. doi: 10.1016/j.neulet.2011.06.054

Martin, S. B., Dowling, A. L., and Head, E. (2011b). Therapeutic interventions targeting $\beta$ amyloid pathogenesis in an aging dog model. Curr. Neuropharmacol. 9, 651-661. doi: 10.2174/157015911798376217

Masliah, E., Hansen, L., Adame, A., Crews, L., Bard, F., Lee, C., et al. (2005). A $\beta$ vaccination effects on plaque pathology in the absence of encephalitis in Alzheimer disease. Neurology 64, 129-131. doi: 10.1212/01.WNL.0000148590.39911.DF

McKhann, G., Drachman, D., Folstein, M., Katzman, R., Price, D., and Stadlan, E. M. (1984). Clinical Diagnosis of Alzheimer's disease: report of the NINCDS-ADRDA work group under the auspices of Department of Health and Human Services task force on Alzheimer's disease. Neurology 34, 939-944. doi: 10.1212/WNL.34.7.939

Meltzer, C. C., Smith, G., DeKosky, S. T., Pollock, B. G., Mathis, C. A., Moore, R. Y., et al. (1998). Serotonin in aging, late-life depression, and Alzheimer's disease: the emerging role of functional imaging. Neuropsychopharmacology 18, 407-430. doi: $10.1016 /$ S0893-133X(97)00194-2

Milgram, N. W., Adams, B., Callahan, H., Head, E., Mackay, W., Thirlwell, C., et al. (1999). Landmark discrimination learning in the dog. Learn. Mem. 6, 54-61.

Milgram, N. W., Head, E., Muggenburg, B. A., Holowachuk, D., Murphey, H., Estrada, J., et al. (2002a). Landmark discrimination learning in the dog: effects of age, an antioxidant fortified diet, and cognitive strategy. Neurosci. Biobehav. Rev. 26, 679-695. doi: 10.1016/S0149-7634(02)00039-8

Milgram, N. W., Zicker, S. C., Head, E., Muggenburg, B. A., Murphey, H., Ikeda-Douglas, C. J., et al. (2002b). Dietary enrichment counteracts ageassociated cognitive dysfunction in canines. Neurobiol. Aging 23, 737-745. doi: 10.1016/S0197-4580(02)00020-9

Milgram, N. W., Head, E., Weiner, E., and Thomas, E. (1994). Cognitive function and aging in the dog: acquisition of nonspatial visual tasks. Behav. Neurosci. 108, 57-68. doi: 10.1037/0735-7044.108.1.57

Milgram, N. W., Head, E., Zicker, S. C., Ikeda-Douglas, C., Murphey, H., Muggenberg, B. A., et al. (2004). Long-term treatment with antioxidants and a program of behavioral enrichment reduces age-dependent impairment in discrimination and reversal learning in beagle dogs. Exp. Gerontol. 39, 753-765. doi: 10.1016/j.exger.2004.01.007

Milgram, N. W., Head, E., Zicker, S. C., Ikeda-Douglas, C. J., Murphey, H., Muggenburg, B., et al. (2005). Learning ability in aged beagle dogs is preserved by behavioral enrichment and dietary fortification: a two-year longitudinal study. Neurobiol. Aging 26, 77-90. doi: 10.1016/j.neurobiolaging.2004.02.014
Mirra, S. S. (1997). The CERAD neuropathology protocol and consensus recommendations for the postmortem diagnosis of Alzheimer's disease: a commentary. Neurobiol. Aging. 18(Suppl. 4), S91-S94. doi: 10.1016/S0197-4580(97) 00058-4

Montine, T. J., Neely, M. D., Quinn, J. F., Beal, M. F., Markesbery, W. R., Roberts, L. J., et al. (2002). Lipid peroxidation in aging brain and Alzheimer's disease. Free Radic. Biol. Med. 33, 620-626. doi: 10.1016/S0891-5849(02)00807-9

Morris, J. C., Storandt, M., McKeel, D. W. Jr., Rubin, E. H., Price, J. L., Grant, E. A., et al. (1996). Cerebral amyloid deposition and diffuse plaques in "normal" aging: evidence for presymptomatic and very mild Alzheimer's disease. Neurology 46, 707-719. doi: 10.1212/WNL.46.3.707

Morys, J., Narkiewicz, O., Maciejewska, B., Wegiel, J., and Wisniewski, H. M. (1994). Amyloid deposits and loss of neurones in the claustrum of the aged dog. Neuroreport 5, 1825-1828. doi: 10.1097/00001756-199409080-00035

Mullane, K., and Williams, M. (2013). Alzheimer's therapeutics: continued clinical failures question the validity of the amyloid hypothesis-but what lies beyond? Biochem. Pharmacol. 85, 289-305. doi: 10.1016/j.bcp.2012.11.014

Murphy, M. P., Morales, J., Beckett, T. L., Astarita, G., Piomelli, D., Weidner, A., et al. (2010). Changes in cognition and amyloid- $\beta$ processing with long term cholesterol reduction using atorvastatin in aged dogs. J. Alzheimers Dis. 22, 135150. doi: 10.3233/JAD-2010-100639

Nicoll, J. A., Wilkinson, D., Holmes, C., Steart, P., Markham, H., and Weller, R. O. (2003). Neuropathology of human Alzheimer disease after immunization with amyloid- $\beta$ peptide: a case report. Nat. Med. 9, 448-452. doi: 10.1038/nm840

Nicoll, J. A., Yamada, M., Frackowiak, J., Mazur-Kolecka, B., and Weller, R. O. (2004). Cerebral amyloid angiopathy plays a direct role in the pathogenesis of Alzheimer's disease. Pro-CAA position statement. Neurobiol. Aging 25, 589-597; discussion 603-604. doi: 10.1016/j.neurobiolaging.2004.02.003

Opii, W. O., Joshi, G., Head, E., Milgram, N. W., Muggenburg, B. A., Klein, J. B., et al. (2008). Proteomic identification of brain proteins in the canine model of human aging following a long-term treatment with antioxidants and a program of behavioral enrichment: relevance to Alzheimer's disease. Neurobiol. Aging 29, 51-70. doi: 10.1016/j.neurobiolaging.2006.09.012

Overk, C. R., and Masliah, E. (2014). Pathogenesis of synaptic degeneration in Alzheimer's disease and Lewy body disease. Biochem. Pharmacol. doi: 10.1016/j.bcp.2014.01.015

Pan, Y., Larson, B., Araujo, J. A., Lau, W., de Rivera, C., Santana, R., et al. (2010). Dietary supplementation with medium-chain TAG has long-lasting cognition-enhancing effects in aged dogs. Br. J. Nutr. 103, 1746-1754. doi: $10.1017 /$ S0007114510000097

Papaioannou, N., Tooten, P. C. J., van Ederen, A. M., Bohl, J. R. E., Rofina, J., Tsangaris, T., et al. (2001). Immunohistochemical investigation of the brain of aged dogs. I. Detection of neurofibrillary tangles and of 4-hydroxynonenal protein, an oxidative damage product, in senile plaques. Amyloid 8, 11-21. doi: 10.3109/13506120108993810

Parker, H. G., Kim, L. V., Sutter, N. B., Carlson, S., Lorentzen, T. D., Malek, T. B., et al. (2004). Genetic structure of the purebred domestic dog. Science 304, 1160-1164. doi: $10.1126 /$ science. 1097406

Peremans, K., Audenaert, K., Blanckaert, P., Jacobs, F., Coopman, F., Verschooten, F., et al. (2002). Effects of aging on brain perfusion and serotonin-2A receptor binding in the normal canine brain measured with single photon emission tomography. Prog. Neuropsychopharmacol. Biol. Psychiatry 26, 1393-1404. doi: 10.1016/S0278-5846(02)00306-8

Petanceska, S. S., DeRosa, S., Olm, V., Diaz, N., Sharma, A., Thomas-Bryant, T., et al. (2002). Statin therapy for Alzheimer's disease: will it work? J. Mol. Neurosci. 19, 155-161. doi: 10.1007/s12031-002-0026-2

Pohl, W. (1973). Dissociation of spatial discrimination deficits following frontal and parietal lesions in monkeys. J. Comp. Physiol. Psychol. 82, 227-239. doi: $10.1037 / \mathrm{h} 0033922$

Pop, V., Head, E., Berchtold, N. C., Glabe, C. G., Studzinski, C. M., Weidner, A. M., etal. (2010a). A $\beta$ aggregation profiles and shifts in APP processing favor amyloidogenesis in canines. Neurobiol. Aging 33, 108-120. doi: 10.1016/j.neurobiolaging.2010.02.008

Pop, V., Head, E., Hill, M. A., Gillen, D., Berchtold, N. C., Muggenburg, B. A., et al. (2010b). Synergistic effects of long-term antioxidant diet and behavioral enrichment on $\beta$-amyloid load and non-amyloidogenic processing in aged canines. J. Neurosci. 30, 9831-9839. doi: 10.1523/JNEUROSCI.6194-09. 2010 
Pratico, D., Clark, C. M., Liun, F., Lee, V. Y.-M., and Trojanowski, J. Q. (2002). Increase of brain oxidative stress in mild cognitive impairment. Arch. Neurol. 59, 972-976. doi: 10.1001/archneur.59.6.972

Price, J. L., Ko, A. I., Wade, M. J., Tsou, S. K., McKeel, D. W., and Morris, J. C. (2001). Neuron number in the entorhinal cortex and CA1 in preclinical Alzheimer disease. Arch. Neurol. 58, 1395-1402. doi: 10.1001/archneur.58.9.1395

Prior, R., D’Urso, D., Frank, R., Prikulis, I., and Pavlakovic, G. (1996). Loss of vessel wall viability in cerebral amyloid angiopathy. Neuroreport 7, 562. doi 10.1097/00001756-199601310-00044

Pugliese, M., Carrasco, J. L., Geloso, M. C., Mascort, J., Michetti, F., and Mahy, N. (2004). Gamma-aminobutyric acidergic interneuron vulnerability to aging in canine prefrontal cortex. J. Neurosci. Res. 77, 913-920. doi: 10.1002/jnr.20223

Pugliese, M., Gangitano, C., Ceccariglia, S., Carrasco, J. L., Del Fa, A., Rodriguez, M. J., et al. (2007). Canine cognitive dysfunction and the cerebellum: acetylcholinesterase reduction, neuronal and glial changes. Brain Res. 1139, 85-94. doi: 10.1016/j.brainres.2006.12.090

Pugliese, M., Geloso, M. C., Carrasco, J. L., Mascort, J., Michetti, F., and Mahy, N. (2006a). Canine cognitive deficit correlates with diffuse plaque maturation and $\mathrm{S} 100 \beta(-)$ astrocytosis but not with insulin cerebrospinal fluid level. Acto Neuropathol. 111, 519-528. doi: 10.1007/s00401-006-0052-1

Pugliese, M., Mascort, J., Mahy, N., and Ferrer, I. (2006b). Diffuse $\beta$-amyloid plaques and hyperphosphorylated tau are unrelated processes in aged dogs with behavioral deficits. Acta Neuropathol. 112, 175-183. doi: 10.1007/s00401-0060087-3

Rapp, P. R. (1990). Visual discrimination and reversal learning in the aged monkey (Macaca mulatta). Behav. Neurosci. 6, 876-884. doi: 10.1037/0735-7044.104.6.876

Raz, N., Gunning-Dixon, F. M., Head, D., Dupuis, J. H., and Acker, J. D. (1998). Neuroanatomical correlates of cognitive aging: evidence from structural magnetic resonance imaging. Neuropsychology 12, 95-114. doi: 10.1037/0894-4105.12.1.95

Rensink, A. A., de Waal, R. M., Kremer, B., and Verbeek, M. M. (2003). Pathogenesis of cerebral amyloid angiopathy. Brain Res. Brain Res. Rev. 43, 207-223. doi: 10.1016/j.brainresrev.2003.08.001

Rissman, R. A., De Blas, A. L., and Armstrong, D. M. (2007). GABA receptors in aging and Alzheimer's disease. J. Neurochem. 103, 1285-1292. doi: 10.1111/j.14714159.2007.04832.x

Rockwood, K., Kirkland, S., Hogan, D. B., MacKnight, C., Merry, H., Verreault, R., et al. (2002). Use of lipid-lowering agents, indication bias, and the risk of dementia in community-dwelling elderly people. Arch. Neurol. 59, 223-227. doi: 10.1001/archneur.59.2.223

Rodriguez, E. G., Dodge, H. H., Birzescu, M. A., Stoehr, G. P., and Ganguli, M. (2002). Use of lipid-lowering drugs in older adults with and without dementia: a community-based epidemiological study. J. Am. Geriatr. Soc. 50, 1852-1856. doi: 10.1046/j.1532-5415.2002.50515.x

Rofina, J. E., Singh, K., Skoumalova-Vesela, A., van Ederen, A. M., van Asten, A. J., Wilhelm, J., et al. (2004). Histochemical accumulation of oxidative damage products is associated with Alzheimer-like pathology in the canine. Amyloid 11, 90-100. doi: 10.1080/13506120412331285779

Rofina, J. E., van Ederen, A. M., Toussaint, M. J., Secreve, M., van der Spek, A., van der Meer, I., et al. (2006). Cognitive disturbances in old dogs suffering from the canine counterpart of Alzheimer's disease. Brain Res. 1069, 216-226. doi: 10.1016/j.brainres.2005.11.021

Russell, M. J., Bobik, M., White, R. G., Hou, Y., Benjamin, S. A., and Geddes, J. W. (1996). Age-specific onset of $\beta$-amyloid in beagle brains. Neurobiol. Aging 17, 269-273. doi: 10.1016/0197-4580(95)02072-1

Russell, M. J., White, R., Patel, E., Markesbery, W. R., Watson, C. R., and Geddes, J. W. (1992). Familial influence on plaque formation in the beagle brain. Neuroreport 3, 1093-1096. doi: 10.1097/00001756-199212000-00015

Sarasa, L., Allue, J. A., Pesini, P., Gonzalez-Martinez, A., and Sarasa, M. (2013). Identification of $\beta$-amyloid species in canine cerebrospinal fluid by mass spectrometry. Neurobiol. Aging 34, 2125-2132. doi: 10.1016/j.neurobiolaging.2013. 03.009

Satou, T., Cummings, B. J., Head, E., Nielson, K. A., Hahn, F. F., Milgram, N. W., et al. (1997). The progression of $\beta$-amyloid deposition in the frontal cortex of the aged canine. Brain Res. 774, 35-43. doi: 10.1016/S0006-8993(97) 81684-8

Schenk, D., Barbour, R., Dunn, W., Gordon, G., Grajeda, H., Guido, T., et al. (1999). Immunization with amyloid- $\beta$ attenuates Alzheimer-disease-like pathology in the PDAPP mouse. Nature 400, 173-177. doi: 10.1038/22124
Schliebs, R., and Arendt, T. (2006). The significance of the cholinergic system in the brain during aging and in Alzheimer's disease. J. Neural Transm. 113, 1625-1644. doi: 10.1007/s00702-006-0579-2

Selkoe, D. J. (2008). Soluble oligomers of the amyloid $\beta$-protein impair synaptic plasticity and behavior. Behav. Brain Res. 192, 106-113. doi: 10.1016/j.bbr.2008.02.016

Selkoe, D. J., Bell, D. S., Podlisny, M. B., Price, D. L., and Cork, L. C. (1987) Conservation of brain amyloid proteins in aged mammals and humans with Alzheimer's disease. Science 235, 873-877. doi: 10.1126/science.3544219

Simic, G., Kostovic, I., Winblad, B., and Bogdanovic, N. (1997). Volume and number of neurons of the human hippocampal formation in normal aging and Alzheimer's disease. J. Comp. Neurol. 379, 482-494. doi: 10.1002/(SICI)10969861(19970324)379:4<482::AID-CNE2>3.0.CO;2-Z

Simons, M., Keller, P., Strooper, B. D., Beyreuther, K., Dotti, C. G., and Simons, K. (1998). Cholesterol depletion inhibits the generation of $\beta$-amyloid in hippocampal neurons. Proc. Natl. Acad. Sci. U.S.A. 95, 6460-6464. doi: 10.1073/pnas.95.11.6460

Simons, M., Schwarzler, F., Lutjohann, D., von Bergmann, K., Beyreuther, K., Dichgans, J., et al. (2002). Treatment with simvastatin in normocholesterolemic patients with Alzheimer's disease: a 26-week randomized, placebo-controlled, double-blind trial. Ann. Neurol. 52, 346-350. doi: 10.1002/ana.10292

Siwak, C. T., Gruet, P., Woehrle, F., Schneider, M., Muggenburg, B. A., Murphey, H. L., et al. (2000). Behavioral activating effects of adrafinil in aged canines. Pharmacol. Biochem. Behav. 66, 293-300. doi: 10.1016/S0091-3057(00)00188-X

Siwak, C. T., Tapp, P. D., Head, E., Zicker, S. C., Murphey, H. L., Muggenburg, B A., et al. (2005). Chronic antioxidant and mitochondrial cofactor administration improves discrimination learning in aged but not young dogs. Prog. Neuropsychopharmacol. Biol. Psychiatry 29, 461-469. doi: 10.1016/j.pnpbp.2004.12.011

Siwak, C. T., Tapp, P. D., and Milgram, N. W. (2001). Effect of age and level of cognitive function on spontaneous and exploratory behaviors in the beagle dog. Learn. Mem. 8, 317-325. doi: 10.1101/lm.41701

Siwak-Tapp, C. T., Head, E., Muggenburg, B. A., Milgram, N. W., and Cotman, C. W. (2007). Neurogenesis decreases with age in the canine hippocampus and correlates with cognitive function. Neurobiol. Learn. Mem. 88, 249-259. doi: 10.1016/j.nlm.2007.05.001

Siwak-Tapp, C. T., Head, E., Muggenburg, B. A., Milgram, N. W., and Cotman, C. W. (2008). Region specific neuron loss in the aged canine hippocampus is reduced by enrichment. Neurobiol. Aging 29, 39-50. doi: 10.1016/j.neurobiolaging.2006.09.018

Skoumalova, A., Rofina, J., Schwippelova, Z., Gruys, E., and Wilhelm, J. (2003). The role of free radicals in canine counterpart of senile dementia of the Alzheimer type. Exp. Gerontol. 38, 711-719. doi: 10.1016/S0531-5565(03)00071-8

Smith, C. D., Carney, J. M., Starke-Reed, P. E., Oliver, C. N., Stadtman, E. R., Floyd, R. A., et al. (1991). Excess brain protein oxidation and enzyme dysfunction in normal aging and in Alzheimer disease. Proc. Natl. Acad. Sci. U.S.A. 88, 10540-10543. doi: 10.1073/pnas.88.23.10540

Smith, M. A., Rottkamp, C. A., Nunomura, A., Raina, A. K., and Perry, G. (2000). Oxidative stress in Alzheimer's disease. Biochim. Biophys. Acta 1502, 139-144. doi: 10.1016/S0925-4439(00)00040-5

Smith, M. A., Sayre, L. M., Monnier, V. M., and Perry, G. (1996). Oxidative posttranslational modifications in Alzheimer's disease. Mol. Chem. Neuropathol. 28, 41-48. doi: 10.1007/BF02815203

Sparks, D. L., Connor, D. J., Sabbagh, M. N., Petersen, R. B., Lopez, J., and Browne, P. (2006a). Circulating cholesterol levels, apolipoprotein E genotype and dementia severity influence the benefit of atorvastatin treatment in Alzheimer's disease: results of the Alzheimer's Disease Cholesterol-Lowering Treatment (ADCLT) trial. Acta Neurol. Scand. Suppl. 185, 3-7. doi: 10.1111/j.1600-0404.2006.00690.x

Sparks, D. L., Sabbagh, M., Connor, D., Soares, H., Lopez, J., Stankovic, G., et al. (2006b). Statin therapy in Alzheimer's disease. Acta Neurol. Scand. Suppl. 185, 78-86. doi: 10.1111/j.1600-0404.2006.00689.x

Sparks, D. L., Sabbagh, M. N., Connor, D. J., Lopez, J., Launer, L. J., Browne, P., et al. (2005a). Atorvastatin for the treatment of mild to moderate Alzheimer disease: preliminary results. Arch. Neurol. 62, 753-757. doi: 10.1001/archneur.62.5.753

Sparks, D. L., Sabbagh, M. N., Connor, D. J., Lopez, J., Launer, L. J., Petanceska, S., et al. (2005b). Atorvastatin therapy lowers circulating cholesterol but not free radical activity in advance of identifiable clinical benefit in the treatment of mild-to-moderate AD. Curr. Alzheimer Res. 2, 343-353. doi: $10.2174 / 1567205054367900$ 
Studzinski, C. M., Christie, L. A., Araujo, J. A., Burnham, W. M., Head, E., Cotman, C. W., et al. (2006). Visuospatial function in the beagle dog: an early marker of cognitive decline in a model of human aging and dementia. Neurobiol. Learn. Mem. 86, 197-204. doi: 10.1016/j.nlm.2006.02.005

Su, M.-Y., Head, E., Brooks, W. M., Wang, Z., Muggenberg, B. A., Adam, G. E., et al. (1998). MR Imaging of anatomic and vascular characteristics in a canine mode of human aging. Neurobiol. Aging 19, 479-485. doi: 10.1016/S0197-4580(98) 00081-5

Su, M. Y., Tapp, P. D., Vu, L., Chen, Y. F., Chu, Y., Muggenburg, B., et al. (2005). A longitudinal study of brain morphometrics using serial magnetic resonance imaging analysis in a canine model of aging. Prog. Neuropsychopharmacol. Biol. Psychiatry 29, 389-397. doi: 10.1016/j.pnpbp.2004.12.005

Tapp, D., Siwak, C. T., Zicker, S. C., Head, E., Muggenburg, B. A., Cotman, C. W., et al. (2003a). An antioxidant enriched diet improves concept learning in aged dogs. Soc. Neurosci. Abstr. 836, 12.

Tapp, P. D., Siwak, C. T., Estrada, J., Head, E., Muggenburg, B. A., Cotman, C. W., et al. (2003b). Size and reversal learning in the beagle dog as a measure of executive function and inhibitory control in aging. Learn. Mem. 10, 64-73. doi: 10.1101/lm.54403

Tapp, P. D., Siwak, C. T., Gao, F. Q., Chiou, J. Y., Black, S. E., Head, E., et al. (2004a). Frontal lobe volume, function, and $\beta$-amyloid pathology in a canine model of aging. J. Neurosci. 24, 8205-8213. doi: 10.1523/JNEUROSCI.1339-04.2004

Tapp, P. D., Siwak, C. T., Head, E., Cotman, C. W., Murphey, H., Muggenburg, B. A. et al. (2004b). Concept abstraction in the aging dog: development of a protocol using successive discrimination and size concept tasks. Behav. Brain Res. 153, 199-210. doi: 10.1016/j.bbr.2003.12.003

Thal, D. R., Rub, U., Orantes, M., and Braak, H. (2002). Phases of A $\beta$-deposition in the human brain and its relevance for the development of, AD. Neurology 58 , 1791-1800. doi: 10.1212/WNL.58.12.1791

Thelen, K. M., Rentsch, K. M., Gutteck, U., Heverin, M., Olin, M., Andersson, U., et al. (2006). Brain cholesterol synthesis in mice is affected by high dose of simvastatin but not of pravastatin. J. Pharmacol. Exp. Ther. 316, 1146-1152. doi: 10.1124/jpet.105.094136

Todd, P. A., and Goa, K. L. (1990). Simvastatin. a review of its pharmacological properties and therapeutic potential in hypercholesterolaemia. Drugs 40, 583607. doi: 10.2165/00003495-199040040-00007

Tomic, J. L., Pensalfini, A., Head, E., and Glabe, C. G. (2009). Soluble fibrillar oligomer levels are elevated in Alzheimer's disease brain and correlate with cognitive dysfunction. Neurobiol. Dis. 35, 352-358. doi: 10.1016/j.nbd.2009.05.024

Torp, R., Head, E., and Cotman, C. W. (2000a). Ultrastructural analyses of $\beta$-amyloid in the aged dog brain: neuronal $\beta$-amyloid is localized to the plasma membrane. Prog. Neuropsychopharmacol. Biol. Psychiatry 24, 801-810. doi: 10.1016/S02785846(00)00107-X

Torp, R., Head, E., Milgram, N. W., Hahn, F., Ottersen, O. P., and Cotman, C. W. (2000b). Ultrastructural evidence of fibrillar $\beta$-amyloid associated with neuronal membranes in behaviorally characterized aged dog brains. Neuroscience 93,495 506. doi: 10.1016/S0306-4522(99)00568-0

Uchida, K., Miyauchi, Y., Nakayama, H., and Goto, N. (1990). Amyloid angiopathy with cerebral hemorrhage and senile plaque in aged dogs. Nihon Juigaku Zasshi 52, 605-611. doi: 10.1292/jvms1939.52.605

Uchida, K., Nakayama, H., and Goto, N. (1991). Pathological studies on cerebral amyloid angiopathy, senile plaques and amyloid deposition in visceral organs in aged dogs. J. Vet. Med. Sci. 53, 1037-1042. doi: 10.1292/jvms.53. 1037

Uchida, K., Tani, Y., Uetsuka, K., Nakayama, H., and Goto, N. (1992). Immunohistochemical studies on canine cerebral amyloid angiopathy and senile plaques. $J$. Vet. Med. Sci. 54, 659-667. doi: 10.1292/jvms.54.659
Walker, L. C., Kitt, C. A., Struble, R. J., Wagster, M. V., Price, D. L., and Cork, L. C. (1988). The neural basis of memory decline in aged monkeys. Neurobiol. Aging 9, 657-666. doi: 10.1016/S0197-4580(88)80130-1

Walsh, D. M., Klyubin, I., Fadeeva, J. V., Rowan, M. J., and Selkoe, D. J. (2002). Amyloid- $\beta$ oligomers: their production, toxicity and therapeutic inhibition. Biochem. Soc. Trans. 30, 552-557. doi: 10.1042/BST0300552

Warren, J. M. (1964). "The behavior of carnivores and primates with lesions in the prefrontal cortex," in The Frontal Granular Cortex and Behavior, eds J. M. Warren and K. Akert (New York: McGraw-Hill Book Company), 168-191.

Wegiel, J., Wisniewski, H. M., and Soltysiak, Z. (1998). Region- and cell-typespecific pattern of tau phosphorylation in dog brain. Brain Res. 802, 259-266. doi: 10.1016/S0006-8993(98)00542-3

West, M. J. (1993). Regionally specific loss of neurons in the aging human hippocampus. Neurobiol. Aging 14, 287-293. doi: 10.1016/0197-4580(93)90113-P

West, M. J., Coleman, P. D., Flood, D. G., and Troncoso, J. C. (1994). Differences in the pattern of hippocampal neuronal loss in normal ageing and Alzheimer's disease. Lancet 344, 769-772. doi: 10.1016/S0140-6736(94)92338-8

West, M. J., Kawas, C. H., Martin, L. J., and Troncoso, J. C. (2000). The CA1 region of the human hippocampus is a hot spot in Alzheimer's disease. Ann. N. Y. Acad. Sci. 908, 255-259. doi: 10.1111/j.1749-6632.2000.tb06652.x

Wisniewski, H. M., Johnson, A. B., Raine, C. S., Kay, W. J., and Terry, R. D. (1970). Senile plaques and cerebral amyloidosis in aged dogs. Lab. Investig. 23, 287-296.

Wisniewski, H. M., Wegiel, J., Morys, J., Bancher, C., Soltysiak, Z., and Kim, K. S. (1990). "Aged dogs: an animal model to study $\beta$-protein amyloidogenesis," in Alzheimer's Disease Epidemiology, Neuropathology: Neurochemistry and Clinics, eds K. Maurer, R. Riederer, and H. Beckman (New York: Springer-Verlag), 151167. doi: 10.1007/978-3-7091-3396-5_15

Wisniewski, T., Lalowski, M., Bobik, M., Russell, M., Strosznajder, J., and Frangione, B. (1996). Amyloid $\beta$ 1-42 deposits do not lead to Alzheimer's neuritic plaques in aged dogs. Biochem. J. 313, 575-580.

Wolozin, B., Kellman, W., Ruosseau, P., Celesia, G. G., and Siegel, G. (2000). Decreased prevalence of Alzheimer disease associated with 3-hydroxy3-methyglutaryl coenzyme a reductase inhibitors. Arch. Neurol. 57, 1439-1443. doi: 10.1001/archneur.57.10.1439

Wolozin, B., Wang, S. W., Li, N. C., Lee, A., Lee, T. A., and Kazis, L. E. (2007). Simvastatin is associated with a reduced incidence of dementia and Parkinson's disease. BMC Med. 5:20. doi: 10.1186/1741-7015-5-20

Zamrini, E., McGwin, G., and Roseman, J. M. (2004). Association between statin use and Alzheimer's disease. Neuroepidemiology 23, 94-98. doi: 10.1159/000073981

Conflict of Interest Statement: The authors declare that the research was conducted in the absence of any commercial or financial relationships that could be construed as a potential conflict of interest.

Received: 03 February 2014; accepted: 28 February 2014; published online: 21 March 2014.

Citation: Davis PR and Head E (2014) Prevention approaches in a preclinical canine model of Alzheimer's disease: benefits and challenges. Front. Pharmacol. 5:47. doi: 10.3389/fphar.2014.00047

This article was submitted to Experimental Pharmacology and Drug Discovery, a section of the journal Frontiers in Pharmacology.

Copyright (C) 2014 Davis and Head. This is an open-access article distributed under the terms of the Creative Commons Attribution License (CC BY). The use, distribution or reproduction in other forums is permitted, provided the original author(s) or licensor are credited and that the original publication in this journal is cited, in accordance with accepted academic practice. No use, distribution or reproduction is permitted which does not comply with these terms. 